NBER WORKING PAPER SERIES

\title{
LOCATE YOUR NEAREST EXIT: \\ MASS LAYOFFS AND LOCAL LABOR MARKET RESPONSE
}

\author{
Andrew Foote \\ Michel Grosz \\ Ann Huff Stevens \\ Working Paper 21618 \\ http://www.nber.org/papers/w21618 \\ NATIONAL BUREAU OF ECONOMIC RESEARCH \\ 1050 Massachusetts Avenue \\ Cambridge, MA 02138 \\ October 2015
}

We are grateful to David Autor, Ben Hansen, and Giovanni Peri for their useful comments and suggestions, and to Nancy Early for her generous help and data expertise. We also thank seminar participants at Texas A\&M, UC Davis, UCSD, the 2015 Population Association of America meeting, and the 2014 Western Economic Association meeting, This research was supported by the U.S. Social Security Administration through grant \#1DRC12000002-03 to the National Bureau of Economic Research as part of the SSA Disability Research Consortium. The findings, opinions and conclusions expressed herein are solely those of the author(s) and do not necessarily represent the views of the U.S. Census Bureau, the SSA, any agency of the Federal Government, or the the National Bureau of Economic Research. The research in this paper does not use any confidential Census Bureau information and was undertaken while Foote was at University of California, Davis.

At least one co-author has disclosed a financial relationship of potential relevance for this research. Further information is available online at http://www.nber.org/papers/w21618.ack

NBER working papers are circulated for discussion and comment purposes. They have not been peerreviewed or been subject to the review by the NBER Board of Directors that accompanies official NBER publications.

(C) 2015 by Andrew Foote, Michel Grosz, and Ann Huff Stevens. All rights reserved. Short sections of text, not to exceed two paragraphs, may be quoted without explicit permission provided that full credit, including $\odot$ notice, is given to the source. 
Locate Your Nearest Exit: Mass Layoffs and Local Labor Market Response

Andrew Foote, Michel Grosz, and Ann Huff Stevens

NBER Working Paper No. 21618

October 2015

JEL No. H55,J01,J63,R23

\section{ABSTRACT}

Large shocks to local labor markets can cause long-lasting changes to employment, unemployment and the local labor force. This study examines the relationship between mass layoffs and the long-run size of the local labor force. It considers four main channels through which the local labor force may adjust: in-migration, out-migration, retirement, and disability insurance enrollment. We show that these channels account for over half of the labor force reductions following a mass layoff event. By measuring the residual difference between these channels and net labor force change, we also show that labor force non-participation accounted for much of the local labor force response in the period during and after the Great Recession.

Andrew Foote

U.S. Census Bureau

4600 Silverhill Road

Suitland, MD 20746

andrew.foote@census.gov

Michel Grosz

University of California, Davis

One Shields Avenue

Department of Economics

Davis, CA 95616

mgrosz@ucdavis.edu
Ann Huff Stevens

Department of Economics

One Shields Avenue

University of California, Davis

Davis, CA 95616

and NBER

annstevens@ucdavis.edu 


\section{$1 \quad$ Introduction}

Over the course of the Great Recession, rates of job loss in the United States reached record highs. As the recovery continues, understanding the nature and speed of labor market adjustment is more important than ever. At the national level, much of the public attention and media coverage has been on overall levels of job creation and economic activity. Variation in the severity of the downturn across local areas points to a need to focus the policy discussion on re-allocating workers to jobs. Well-known work by Blanchard and Katz (1992) originally emphasized the importance of labor mobility in this adjustment process, showing that local unemployment rates primarily adjust by workers moving to areas where there are more jobs, as opposed to local job creation. During the Great Recession, reports of significantly reduced mobility (Frey 2009) have added to concerns that housing market factors and low mobility may prolong recovery time.

In this paper, we examine the relationship between negative local labor market shocks - many of which occurred during the recent recession - and labor force changes. Specifically, we ask whether, and to what extent, internal migration and other exits from the local labor force follow negative shocks and facilitate adjustments in an area's labor supply. We measure changes in county labor force size, migration, retirement and disability insurance enrollment that occur after large layoff events.

There are several benefits to using mass layoffs as the measure of local labor demand shocks. First, we avoid the endogeneity of local unemployment rates with respect to changes in labor supply and migration patterns. Second, the mass layoffs afford us the opportunity to analyze responses to local labor demand shocks that are discrete and do not occur over the course of several years. Further, since mass layoffs are defined as the permanent release of at least 50 workers from a single establishment, they represent a concentrated shock to local labor demand.

We first measure the net change in the size of the local labor force in response to a mass layoff. While there are a variety of causes for these labor force changes, we focus on four main channels of labor market exit — in-migration, out-migration, disability insurance enrollment, and retirement - and estimate the relative importance of these channels as exits from the labor force. These four exit channels jointly account for most 
of the observed net changes in labor force, and we argue that the residual mainly captures labor force non-participation. We show that while migration is the predominant channel of labor force exit, non-participation grew in importance during the Great Recession.

This paper makes several contributions to the literature. First, we jointly consider all potential labor force exit channels, and compare their relative importance in explaining changes in labor force size. Second, we measure the role of migration as an adjustment mechanism in the aftermath of significant mass layoffs affecting an area's residents. While the relationship between unemployment rates and migration has been studied extensively, we are the first to directly and systematically link mass layoff events to mobility into and out of areas. Finally, we document the rising importance of nonparticipation following local labor demand shocks in recent years, and discuss potential reasons for that change.

\section{Literature Review}

There is a substantial literature on the effect of labor demand shocks on migration. Blanchard and Katz (1992) show that after a negative employment shock, employment in a local labor market falls and then recovers somewhat, but never returns to its original level. They conclude that most of this effect is due to migration. Here, we update and extend their approach in order to more directly document the size of these flows out of labor markets following a negative labor demand shock.

Bound and Holzer (2000) measure the responsiveness of specific populations between the 1980 and 1990 Censuses to labor market shocks. They show that low-skilled workers, particularly low-skilled black workers, migrate relatively little in response to labor market shocks. We re-examine this issue using mass layoffs. We also include measures of population changes by age and race groups, which allow us to examine how labor force responses to mass layoffs affect an area's demographic composition.

Notowidigdo (2013) extends Bound and Holzer's (2000) analysis and employs a similar method, but argues that lower-skilled workers are less likely to migrate because they bear a smaller incidence of local labor demand shocks. He shows that following adverse labor demand shocks, public assistance program spending increases and housing costs decline, which both disproportionately impact low-skilled workers and make them 
less likely to migrate. He also notes that some of the decline in local employment is due to a decline in labor force participation, and cannot be entirely attributed to outmigration. Our work directly measures these channels, in order to assess the importance of non-participation.

Saks and Wozniak (2011) show that migration is pro-cyclical at the national level; in times of low national unemployment, the benefits from moving are higher, inducing more people to migrate for job-related reasons. Additionally, when controlling for national-level labor demand, they find that state-level labor demand is still a significant determinant of migration.

In this paper, we examine shocks that are more acute and localized than statelevel unemployment changes, by measuring mass layoff events at the county level. In addition to migration, we explore how other channels of labor force exit are related to aggregate economic cycles. The first of these is Social Security Disability Insurance enrollment (hereafter DI), whose role as an alternative to job search in economic downturns has been documented in various contexts (Black, Daniel and Sanders, 2002, Burkhauser, Butler and Gumus, 2004, Autor and Duggan 2003). The second additional channel of labor market exit is retirement, which we observe in take-up of Social Security retirement benefits. Workers displaced from jobs late in their careers have substantially lower employment rates than those who are not displaced, which suggests that poor re-employment prospects after mass layoffs cause many workers to opt for early retirement (Chan and Stevens, 2001; Stevens and Chan, 1999). Others suggest that different aspects of the recent economic downturn-the housing market crash, the stock market collapse, and rising unemployment-imply different incentives to either hasten or delay retirement (Coile and Levine, 2011; Bosworth and Burtless, 2010; Goda, Shoven and Slavov, 2012).

Workers, especially those who have been laid off, may also exit the labor force without migrating or substituting their former income with participation in government programs. Especially in hard economic times, unemployed workers may become discouraged and stop looking for work (Erceg and Levin 2013). In the Great Recession, the labor market saw a surge in exits due to discouraged workers, only half of whom eventually reentered the labor market (Ravikumar and Shao 2014, Kwok, Daly and 
Hobijn, 2010). Workers are also more likely to become discouraged or take longer to reenter the labor force if part of a couple, since the other member of the couple may increase job search or enter the labor market, a phenomenon dubbed the added worker effect (Lundberg 1985, Mattingly and Smith 2010). In the Great Recession, as in other economic downturns, labor force participation among teenagers also decreased, as more pursued education or simply did not work or look for jobs (Kwok et al. 2010).

Autor, Dorn and Hanson (2013) use differential exposure to import competition from China to identify areas with adverse labor demand shocks. They find that these shocks lowered labor force participation and increased unemployment, while also increasing transfer payments. While we use a different labor market shock, we come to similar conclusions, showing that non-participation is a key channel of adjustment following a labor demand shock. In contrast, we find effects on the mobility of individuals. Our results on mobility may differ from theirs because they use labor demand shocks on lower-skilled workers, who are not as mobile.

\section{Data}

We compile several datasets to construct a panel of counties spanning the years 1996-2013. Our identification strategy relies on variation in county-level labor demand shocks, as measured by mass layoff events. To measure the size of these shocks, we calculate the share of the county labor force in a given year that that was displaced due to a mass layoff. Between 1996 and 2013, the Bureau of Labor Statistics (BLS) compiled monthly reports on layoffs by observing the initial claims for unemployment insurance filed by workers. The BLS identified a mass layoff event when more than 50 workers filed claims against a single establishment within any five-week period. For these events, the BLS contacted the establishment to determine whether these workers experienced a layoff of at least 31 days. We use data on these mass layoff events at the county level for 1996-2013, including the number of workers directly affected. ${ }^{1}$ Our data are organized by the affected workers' county of residence, so that we measure the number of workers living in a given county who were part of a mass layoff at their past establishment (which

\footnotetext{
${ }^{1}$ In March 2013, in order to abide by the sequestration imposed by the Balanced Budget and Emergency Deficit Control Act, the BLS eliminated the Mass Layoffs Statistics Program.
} 
could be located in a different county). To normalize the magnitude of these layoffs we use annual data on the size of the county labor force, compiled by the Local Area Unemployment Statistics program of the BLS.

Our main outcomes of interest are in-migration flows, out-migration flows, net changes in DI caseload, and net changes in the number of retirees. We use information on migration from the Internal Revenue Service (IRS) Statistics of Income files, which calculate inflows and outflows based on address changes of individual tax filers. As in other research, we use the number of tax returns in a county as an approximation for the number of households, and the number of exemptions for the number of individuals (Molloy, Smith and Wozniak, 2011). We use these data for 1996-2010 to construct measures of the number of individuals moving into and out of a particular county.

While these data are helpful in studying internal migration, they have a few limitations. First and foremost, individuals who do not file taxes (most often the poor and the elderly) do not appear in the data, nor do their households. Moreover, the data only include filers who complete their tax returns at most five months following the April 15 deadline, which excludes some late filers. The data are also limited in their ability to identify changes in filing status; for example, for a married couple that subsequently divorces and files two separate returns, only the migration behavior of the individual who was the primary taxpayer in the initial joint return will be recorded. ${ }^{2}$

To calculate the number of individuals at the county level enrolled in DI and retirement, we use data from the Social Security Administration's Old Age, Survivors and Disability Insurance (OASDI) program from 1999 to 2012. The data report total numbers of beneficiaries each year, but we calculate net changes for use in the analyses. While individuals can claim their retirement benefits almost immediately upon making the decision to retire, DI enrollment occurs long after an applicant files the initial claim. DI rules include a five month waiting period between when the worker meets conditions for disability eligibility and when benefits begin. During these five months, workers must earn less than the "substantial gainful activity" threshold of approximately $\$ 1,000$

${ }^{2}$ A more extended discussion of these data, as well as their strengths and limitations, is in Gross (1999). 
per month. ${ }^{3}$ Applications take many months to be accepted, and applicants can appeal decisions, extending the process. The process lasts around nine months for applications accepted on the first claim (Kreider, 1998), but often lasts more than a year when applicants appeal (Autor et al 2015).

Because of this attribute of the program, other studies that examine DI as a response to labor market shocks (eg. Autor and Duggan, 2003, Black et al., 2002) tend to focus on applications as opposed to acceptances. Thus, for an additional analysis, we use county-level information on DI applications compiled by the Social Security Administration. This dataset, created from the "Disability Research File," includes applications, appeals, and allowances at the county level, by broad age group and gender. The age groupings correspond to those in the Mass Layoffs Statistics: under 30, 30-44, 45-54, and 55 and older. These data are described in more detail in section 5.3.

We express our four outcome variables - in-migration, out-migration, DI enrollment and retirement — as rates, which can be compared to the flows of newly displaced workers from mass layoffs. We define in-migration and out-migration rates as the number of in- or out-migrants to or from a county in a particular year as a share of that county's population that year. For both DI enrollment and retirement, we also divide the net change in new cases by the county's population the previous year, in order to not include the change in the labor force during the same year as the mass layoff.

We supplement these main sources of data with additional information on county demographics and median income. We use county level information on the age, gender, and racial composition of county populations as reported in the Surveillance, Epidemiology, and End Results (SEER) program of the National Cancer Institute, which includes annual data from 1969-2012, as well as county-level median income from the Bureau of Economic Analysis (BEA).

Given that these different datasets cover different time periods, our final dataset spans the years 2000-2010, which are the years in which we have data on all the relevant outcomes.

${ }^{3}$ For more information on the waiting period, see Moulta-Ali (2013). 


\section{$4 \quad$ Methods}

Our goal is to measure the effect of mass layoffs on changes in the labor force, and to quantify the channels of labor market exit and their relative importance. In this section, we describe the outcomes of interest, which are the various types of labor force exits, and how they relate to each other. After this description, we explain the rationale for using mass layoffs as a measure of labor demand shocks. We discuss the limitations of using the unemployment rate, but tie our results to the earlier literature by instrumenting for unemployment rate with the share of the labor force involved in a mass layoff. Second, we illustrate how mass layoffs act as well-defined shocks that are plausibly exogenous with respect to pre-existing trends.

\subsection{Decomposing Changes in the Labor Force}

Consider the following decomposition describing the components of a net labor force change from one year to the next:

$$
L F_{c t}-L F_{c, t-1}=\left(\text { inmigration }_{c t}-\text { outmigration }_{c t}\right)-\text { DI }_{\text {enroll }}+\text { retirement }_{c t}+\varphi_{c t}
$$

The term $L F_{c t}$ is a county c's labor force in year $t$. The above equation shows that changes in the labor force can arise from five different channels. The first two terms on the right-hand side of equation (1) comprise the net migration of workers: in-migration minus out-migration. Any individuals that enroll in DI or retire also change the size of the labor force. The residual, $\varphi_{c t}$, includes all other flows into and out of the labor force not captured by migration, DI, or retirement. Foremost among these other exits from the labor force include individuals aging, workers dying, and new full-time students. Another important component of $\varphi_{c t}$ is individuals of working age not participating in any of these explicit labor force exit channels. ${ }^{4}$

\footnotetext{
${ }^{4}$ While Sullivan and von Wachter (2009) show that job separations such as mass layoffs increase mortality rates for those involved by approximately 50-100\% in the few years following, this effect in aggregate would be neglible; taking their reported baseline mortality, a 1 percent mass layoff would increase mortality rates from 6.76 to 6.83 per 1000 . For this reason, we do not expect our measure of nonparticipation to be impacted by mortality following job loss.
} 
To compare the effect of layoff events across labor markets of different sizes, we normalize the magnitude of these changes and express them as shares. Specifically, we divide both sides of equation (1) above by the size of the population in previous period:

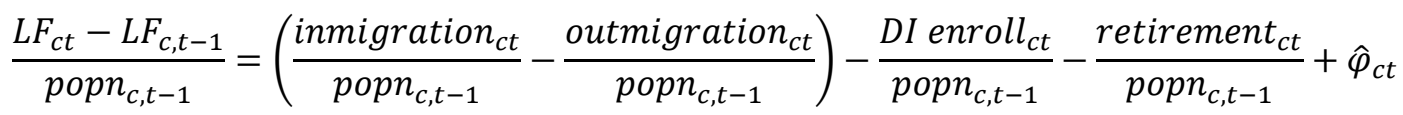

This equation above describes the relationship between our five outcome variables of interest. We estimate the effect of mass layoffs on the components of the right-hand side of equation (2), as well as on the net change in labor force (i.e. the left hand side of equation (2)). The residual $\hat{\varphi}_{c t}$ is just rescaled from the first equation. We normalize in this way in order to avoid scale-effect bias, as described in Peri and Sparber (2011).

Note that in equation (2) above, the in-migration and out-migration specifically refer to labor force participants. While the migration data we use do not separate out workers from non-workers, if we assume that labor force participants and nonparticipants migrate at the same rate, then those two terms do not have to be rescaled.

\subsection{Mass Layoff Counts as an Alternative to County Unemployment Rates}

Understanding the relationship between local labor market shocks and labor force exits presents several challenges. First, a typical approach involves relating local area unemployment rates to local population changes or migration rates. ${ }^{5}$ However, the unemployment rate is itself a function of current and past migration decisions, making causal inference difficult and interpretation of descriptive relationships challenging. Second, analyses are typically done at the state level, which may be too broad to capture a single labor market. One the other hand, local unemployment measures for smaller geographic areas raise serious measurement error concerns.

\footnotetext{
${ }^{5}$ For examples of this, see Greenwood (1997) and Davies, Greenwood and Li (2001). Additionally, Wozniak (2010) uses both unemployment rates and Bartik instruments, while Saks and Wozniak (2011) instrument for unemployment rates with Bartik-type instruments and oil shocks; these instruments are discussed below.
} 
We begin our analysis by measuring the effect of the unemployment rate on labor force exit, knowing the limitations of such an approach. In our context, with local labor market changes measured at the county level, we estimate the following equation:

$$
y_{c t}=\alpha+\beta U R A T E_{c t}+\delta_{t}+\gamma_{c}+\eta_{c} * t+\epsilon_{c t}
$$

Where $y_{c t}$ is a particular type of labor market exit measured at the county level, and $U R A T E_{\mathrm{ct}}$ is the unemployment rate in the county. We also include time fixed effects $\delta_{t}$ and county fixed effects $\gamma_{c}$, as well as county-specific time trends $\eta_{\mathrm{c}}{ }^{*} \mathrm{t}$.

Using the unemployment rate as above introduces three problems into the estimation. First, the unemployment rate is endogenous since it captures labor supply changes in addition to labor demand changes (Bartik 1996). Additionally, changes in the labor force, which are in the denominator of the unemployment rate, are clearly endogenous to migration rates in and out of a local area. Finally, for smaller geographic units the unemployment rate published by the BLS is measured with error (see Bartik, 1996; Hoynes, 2000; Lindo 2015).

For these reasons, researchers often rely on instruments for the unemployment rate. The ideal instrument would address both the endogeneity concerns and concerns with measurement error in the unemployment rate. One such instrument is the shift-share or Bartik instrument (Bartik, 1991) that utilizes pre-existing, area-specific industry structure and changes in industry outcomes at the national level. Such an approach been used successfully at the state and MSA level (Saks and Wozniak, 2011; Bound and Holzer, 2000). However, using a Bartik instrument may be difficult at the county-level due to small samples for measuring county-level industry shares. Additionally, the Bartik instrument does not provide intuition on the relative size of the shock for a county compared to the size of the labor force.

As an alternative, in this study we use the number of mass layoffs at the county level as our measure of local labor demand shocks. In our main results, we move to using mass layoffs directly in a reduced-form setting; this has a direct and substantively interesting interpretation of the effect of a major layoff event on a local area labor force. Mass layoffs are a good alternative to the unemployment rate because they resolve the 
problems that arise when using the county unemployment rate. First, they clearly measure a change in labor demand, and thus are not hampered by endogenous labor supply responses, a claim for which we provide more evidence in the next section. While migration can mechanically reduce the unemployment rate over time, migration does not directly generate mass layoffs. Second, measurement error in the mass layoffs data is most likely uncorrelated with the measurement error in the county unemployment rate.

The main source of measurement error in the mass layoffs data comes from establishments planning a certain number of layoffs and then changing these plans, and is not due a direct result of small sample sizes, since these represent a census of all layoffs of greater than 50 workers.

Mass layoffs are also of independent interest as an observable indicator of a shock to local labor markets that may concern policymakers. Focusing on mass layoffs allows us to directly address the question of how a series of mass layoffs may permanently change the size and composition of the local labor force. Similarly, we can examine how the number of lost jobs translates into individuals leaving a local area.

To establish that mass layoffs are strongly correlated with the unemployment rate, we begin by regressing the unemployment rate on mass layoffs, including the contemporaneous mass layoff share and two lags. Table 1 summarizes the first-stage relationship between the county unemployment rate and mass layoffs as a fraction of the county's labor force. This approach also conditions on county fixed effects, year fixed effects, and county-specific trends. The results suggest that if one percent of a county's labor force is laid off, the unemployment rate rises by 0.33 percentage points that year, and 0.77 percentage points within three years. Not accounting for job creation and changes in the labor force itself — which are our rationale for not using the unemployment rate to begin with - a coefficient less than one suggests that not all the layoffs are permanent. The F-statistic on the mass layoffs is 30.68 , and the results clearly show that mass layoffs are strongly correlated with the unemployment rate.

We next estimate both OLS and instrumental variables versions of equation $3 .^{6}$ We instrument the unemployment rate with a contemporaneous mass layoff rate as well

\footnotetext{
${ }^{6}$ Because the unemployment rate is a stock and not a flow, we only include the contemporaneous unemployment rate, as in Saks and Wozniak (2011).
} 
as two lags. ${ }^{7}$ Our results from this estimation are in Table 2. In Table 2, the first column is the OLS estimate, and the second column is the IV estimate; each outcome variable is in a different panel. Starting with the first panel, we see that a higher unemployment rate decreases the size of the labor force; however, some of that effect may be mechanical, given that labor force is in the denominator of the unemployment rate, which may cause division bias. However, when we instrument for the unemployment rate, in the second column, we see a similar effect, such that a 1 percent increase in the unemployment rate causes the labor force to shrink by approximately 0.2 percentage points.

Additionally, we see small negative effects of the unemployment on rates of inmigration. A one percentage point increase in the unemployment rate leads to a 0.1 percentage point decrease in the in-migration rate, but the IV results are smaller and not statistically different from zero.

For out-migration, the OLS estimates suggest that a one percentage point increase in the unemployment rate increases the out-migration rate by about 0.06 percentage points. The IV results suggest a larger initial effect of the unemployment rate on outmigration, which is consistent with the unemployment rate being endogenous as well as with measurement error pushing the OLS estimate towards zero.

When we look at the effects of unemployment on flows into disability insurance and retirement, we find, as might be expected, smaller responses. This expectation is based on the fact that only a subset of workers in a local area will have an underlying medical condition or be in an age range that is consistent with entering disability insurance or retirement. Nevertheless, the estimated effects do suggest that higher unemployment is associated with small (statistically insignificant) increases in the share of a county's labor force that is retired or using disability insurance, echoing much earlier work. In the remainder of the paper, we focus on the reduced form relationship between mass layoffs and labor force exits.

\footnotetext{
${ }^{7}$ In results not shown, we included different specifications of the number of lags of both the endogenous regressor and the instrument. All the results were similar as the ones shown.
} 


\subsection{Mass Layoffs and Labor Force Exits}

Table 3 (panel A) shows summary statistics for mass layoff variables in the full study period, as well as before and after the start of the Great Recession in 2007 (the second and third columns, respectively). On average, 0.7 percent of a county's labor force was laid off in a mass layoff event each year, which translates to an average of 379 workers. Not surprisingly, these shares differ substantially before and after 2007. Panel B of Table 3 shows the share of counties that experienced at least one year where the share of the labor force involved in a mass layoff surpassed a certain threshold. Most counties (61 percent) had at least one year where one percent of the labor force was laid off. However, a large number of counties also experienced a higher percentage event. Panel C of Table 3 shows the key variables that contribute to the decomposition of the change in labor force as a share of the population. On average, the change in the size of the labor force as a share of the population was 0.3 percent.

To motivate our main analysis, we illustrate the relationships between labor force exits and layoffs using an event study approach. For this analysis, we focus first on counties that experienced large, discrete labor demand shocks, which allows us to examine county trends prior to a major layoff. For these counties, the event study analyses provide suggestive evidence that the large layoff events were unlikely to have been preceded by long-term labor market decline.

We limit the data to the subset of counties in our sample that experience a large layoff event — of two, three, or four percent of the labor force - once between 2001 and 2007. We further limit the sample to counties for which this one-time event occurred before 2007. Layoff rates increased dramatically during the Great Recession making it more difficult to isolate counties with only a single large layoff event after 2007. In this limited sample of 118 counties, these large and isolated layoff events were the most likely to have been unanticipated to local workers and unrelated to local economic trends.

We illustrate this relationship using the following simple event-study model:

$$
y_{c t}=\alpha+\sum_{\substack{i=-6 \\ i \neq-1}}^{6} \beta_{i} 1\left(t-T_{c}=i\right)+\delta_{t}+\gamma_{c}+\epsilon_{c t}
$$


The outcome variable $y_{c t}$ is one of the following: in-migration rate, out-migration rate, new DI enrollment, and new retirement enrollment. We include county and time fixed effects, $\gamma_{c}$ and $\delta_{t}$, to control for fixed differences between counties and a nonparametric national time trend. We define $T_{c}$ as the year the county experienced layoffs surpassing the relevant layoff threshold of two, three or four percent. The indicator 1( $t-$ $T_{c}=i$ ), then, takes a value of one when the observation year is $i$ years from $T_{c}$. For example, if the layoff event happened in 2004, then $1\left(t-T_{c}=i\right)$ would take value one in year 2005 for $i=1$. Observations earlier than six or later than six years from the event are captured by dummies $1\left(t-T_{c} \leq-6\right)$ and $1\left(t-T_{c} \geq 6\right)$. We omit the dummy for $i=-1$, so all the coefficients are relative to the year before the major mass layoff occurred.

Figure 1 displays the coefficients for our event study analysis using the counties involved in a mass layoff of greater than 4 percent of the labor force. The top two graphs of Figure 1 display the coefficients for in- and out-migration, as well as a 95 percent confidence interval. ${ }^{8}$ Importantly, in neither the in-migration nor the out-migration case does there seem to be a noticeable trend in migration rates before the mass layoff event. In-migration and out-migration seem relatively flat in the years previous to the event. Following the event, there does appear to be an increase in out-migration rates. Similarly, there is a noticeable dip in in-migration, which is sustained in the years following mass layoffs.

The bottom half of Figure 1 displays the same analyses for DI and retirement. The estimates are noisier, but the trends prior to mass layoff events do not suggest that there were upward trends in exits to disability or retirement prior to the layoff events. Although the estimates are not statistically significant, DI enrollment seems to increase slightly three years after the layoff event. For retirement, the pattern is also not statistically significant but consistent with our hypothesis of an increase in retirement.

This visual analysis shows that for the counties that experienced only one major mass layoff event in our time period, there were no pre-existing trends in labor force exit paths before the mass layoff event occurred. This further motivates and provides support for our statistical approaches below, which use mass layoffs directly as an indicator of

\footnotetext{
${ }^{8}$ Appendix Figures A1 and A2 shows these results for other lower thresholds for defining large mass layoffs.
} 
local labor market shocks. In the next sections we extend the analysis to all counties in the country—not just the ones that experienced particularly dramatic labor market shocks - and quantify the size of these adjustment processes.

\section{$5 \quad$ Results}

In the previous section, we estimated effects of mass layoff events on a subsample of counties. Now, we estimate the effect for the full sample, using the following equation.

$$
y_{c t}=\alpha+\sum_{i=0}^{2} \beta_{i} \text { layoff } f_{c, t-i}+\delta_{t}+\gamma_{c}+\eta_{c} * t+\epsilon_{c t}
$$

Our key variable of interest is layoff $f_{c t-i}$, which we define as the share of the labor force of county $c$ laid off in year $t$. We also include lagged values of the layoff indicators, since responses to labor demand shocks may take time. Our outcome variable, $y_{c t}$, is either the net labor force change or one of the components: out-migration rate, inmigration rate, new DI enrollment rate, and new retirement rate, all normalized by lagged county population.

We include county fixed effects, $\gamma_{c}$, to control for systematic differences between counties in their labor market, mobility of individuals, and the policy environment. We include year fixed effects, $\delta_{t}$, to control for national trends. In our preferred specification, we also include county-specific trends, $\eta_{c} * t$, in order to control for general trends in a county's labor market and demographic structure. Finally, to address the fact that mass layoffs may be correlated within a state over time, we cluster our standard errors at the state level. ${ }^{9}$

Table 4 shows our main results for out-migration and in-migration. In column 1, we include only the contemporaneous effect of mass layoffs, while columns 2 and 3 add one and two lags, respectively. In column 3, the effect of mass layoffs is large and significant for both out- and in-migration. Additionally, at the bottom of each panel, we total the coefficients to show the total effect of a mass layoff. Our estimates in column 3 imply that when one percent of the county-level labor force is laid off in a mass layoff

\footnotetext{
${ }^{9}$ Clustering our standard errors by state may actually overstate our standard errors, since mass layoff events are likely correlated with nearby counties, but not faraway counties.
} 
event, the out-migration rate increases by about 0.06 percentage points within three years.For in-migration, a one percent mass layoff increase leads to a decrease in inmigration rates by about 0.06 percentage points. ${ }^{10}$

In column 4, we include county-specific trends, which shrink the in-migration estimates substantially, and slightly increase the out-migration estimates. The difference in the coefficient on in-migration when controlling for trends is likely due to the relative persistence and slow response of population flows into a county, and highlights the potential importance of including county-specific trends in the analysis (Rappaport (2004)).

In the rest of the tables we focus on the total effect - that is, the sum of the contemporaneous, lagged, and twice-lagged coefficients displayed in Table 4. Table 5 displays our results for each outcome that is part of the decomposition in the overall labor force change. Given the sensitivity of the in-migration results to county trends, Table 5 presents estimates both with and without county-specific trends. The trends only change the estimates significantly for in-migration, and importantly our estimates for the overall change in the labor force barely change at all. Thus, we focus on the results with trends in most of the discussion.

In column 1 of Table 5, we show that a mass layoff affecting 1 percent of a county's workers leads to a reduction of 0.20 percentage points in the size of the labor force over the next three years. The majority of this change is driven by increased outmigration and decreased in-migration (although the effect on in-migration is not statistically significant). There are positive effects on both DI claims and new retirements, but the estimates are small and not statistically significant. Combined, the point estimates on DI and retirement suggest that these channels account for roughly 5 percent of the overall change in the size of the labor force following mass layoffs.

Summing up our effects across columns, we can explain 53 percent of the change in the labor force with these four channels when including trends, and 76 percent of the change in estimates without trends. To quantify all of the labor market exit channels, we

\footnotetext{
${ }^{10}$ In results not shown we include additional lags to the key explanatory variable. These additional lags are small and not statistically significant providing further evidence that the timeframe of adjustment to labor market shocks is relatively quick.
} 
also calculate the implied residual from equation 2 , and display it in the sixth column. In the results without trends, our results imply a residual of -0.0414 . With trends, we find a slightly larger residual of -0.0921 , which suggests that for a 1 percent mass layoff, the number of people that remain in the area but stop participating in the labor force increases by about 0.09 percentage points.

One important question in the wake of the Great Recession is whether nonparticipation has changed over time. A number of recent papers have sought to investigate this, noting that the labor force participation rate for 25-54 year olds in the Great Recession fell precipitously, and then has not recovered even in the face of an improving economy. Erceg and Levin (2013) show that the Great Recession contributed a large amount to the decline in labor force participation. Charles, Hurst, and Notowidigdo (2013) argue that despite being masked by the housing boom, nonemployment had been secularly increasing in the 2000s, which only revealed itself after the housing market crash. Here, we examine whether labor force non-participation rates increased in the recent recession.

To see how non-participation has changed during the Great Recession, we separate the study period into the years before and the years including and after the Great Recession: 2000-2006 and 2007-2010. To estimate how the effect of a mass layoff changed during the Great Recession, we interact our measure of mass layoffs with a dummy for the year being after 2007. Our estimates from this approach are in Table 6, allowing the effect of a mass layoff to be different before and after the Great Recession. In the table, below the coefficient estimates, we list the total effect for the time period before the recession and after the recession. ${ }^{11}$

Our results show that the non-participation channel grew much larger during the Great Recession. The effect of a 1 percent mass layoff in the pre-recession period caused county labor force size to decrease by about 0.11 percentage points. Additionally, the effect of the mass layoff is large for both out-migration and in-migration, and all the estimates taken together imply a residual of approximately 0.026, implying that our channels over-explain the labor force change.

\footnotetext{
${ }^{11}$ We also estimate each time period separately; however, given the short time period since the Great Recession, if we estimate it separately we are unable to include trends, and so Table 6 shows our preferred approach.
} 
The results are much different for the years after 2007. First, the labor force response to a one percent mass layoff is more than twice as large as before 2007. Second, the out-migration response after 2007 is muted, with a magnitude about half as large as the response before 2007. Taken together, our estimates suggest that migration, retirement, and disability explain only about 33 percent of the total change in the labor force during the recession years, with the residual (non-participation) explaining 67 percent of the net labor force change. These results show that during the Great Recession, migration was not a major channel for labor market adjustment to local shocks. One possibility is that the Great Recession was unique given the role of the housing crisis, which impeded mobility; we return to this possible explanation in a later section. Another possibility is that during recessions more broadly, mobility plays a more limited role in local labor market adjustment than in a non-recessionary period (Saks and Wozniak, 2010). Results showing a limited role for migration are generally consistent with the findings of Notowidigdo (2013), who suggests that migration is not the primary mechanism in the adjustment of local labor markets. This suggests that examinations of labor market adjustment may need to distinguish recessionary and growth periods to understand the nature and speed of local labor force adjustments. Another part of this interpretation is to recognize that a 1 percent mass layoff may represent a larger change to net employment during a recession, since job creation rates are pro-cyclical.

\subsection{Geography of labor force exits}

In addition to exploring heterogeneity before and after the Great Recession, we explore the potential for geographic heterogeneity in the response to labor demand shocks. In particular, responses in urban counties may be different because of differences in the density of job opportunities, distance to other potential jobs in adjacent counties, or attitudes toward and availability of public assistance. Additionally, some counties that are not near cities may be more dependent on a single firm or industry, leading mass layoff events to have an outsized effect. ${ }^{12}$

\footnotetext{
${ }^{12}$ For instance, the economy of rural Greenlee County, Arizona depends on one of the largest copper mines in the world, which in 2001 and 2008 laid off a large number of workers and, thus, a substantial fraction
} 
We categorize counties by whether they were part of a metropolitan statistical area (MSA) as defined in the 1990 Census. We use 1990 MSA definitions in order to fix these definitions before the start of the study period. ${ }^{13}$ We find similar effects for MSA and non-MSA counties, and suggestive evidence that non-participation is higher in rural counties, although the differences are not statistically significant. Additionally, we test whether the effects differ before and after the Great Recession for urban and rural counties, and find similar patterns, but our results have large standard errors. ${ }^{14}$

In addition to categorizing counties by their population, we also examine the distance of movement for individuals who migrate. Fogli, Hill and Perri (2012) argue that individuals displaced from work in one county may migrate to an adjacent county, mechanically increasing its unemployment rate in the receiving county. One advantage of the IRS migration data is that they allow us to decompose the migration response in more detail and thus estimate the size of the different migration types.

We explore whether workers undertake moves across state lines or to adjacent counties. Table 7 shows the results of these decompositions. Column 1 displays the main result from Table 5, while columns 2-5 examine the responses of the four types of migration flows. The results suggest that the majority of people leaving the county following layoffs tend to leave the state (82 percent). Similarly, 99 percent of moves are to non-adjacent counties. These findings suggest that individuals seek moves to a different labor market, rather than simply relocating to reduce housing arrangements or costs.

\subsection{Effects Moderated by County Features}

Following Notowidigdo (2013), we expect the response to a mass layoff to be moderated by the strength of income supports in the local safety net. However, estimating these effects is difficult; while counties vary dramatically in take-up rates of different

of the county's labor force. Likewise, a series of lumber mill closings in northern Idaho in 2000, especially in Benewah County, devastated the local economy, directly affecting four percent of the labor force.

${ }^{13}$ Overall, in 1996, about $25 \%$ of the US population resided in "non-MSA" counties, a share that decreased only slightly during our study period.

${ }^{14}$ These results are available upon request. 
social programs, these differences are often endogenous to other local economic conditions. Additionally, there is very little cross-sectional variation in safety net generosity. One notable exception is unemployment insurance (UI), since states are able to adjust the replacement rate of UI benefits (Kuka 2015, Lalumia 2013). To this end, we use the UI benefit calculator developed by Lalumia (2013) and divide our sample into counties that are in states with UI replacement rates above or below the median in 1996. We find that there are no statistically significant differences between these counties, suggesting that higher UI replacement rates do not affect labor market exit.

One of our key findings is that the pattern of labor force adjustment changed during the Great Recession, and the recession was driven in large part by subprime lending and foreclosures. Using county data from the Home Mortgage Disclosure Act (HMDA) ${ }^{15}$ which compiles detailed information on loan originations, we ranked counties as high or low in terms of the share of home purchase loans that were high-cost (the difference between its APR and a Treasury security with the same maturity was at least 3 percent), since these are loans that were at a higher risk to go into foreclosure. One limitation is that HMDA only began tracking this information in 2004, and so we limit the analysis to 2007-2010 and omit county trends. Overall, we find that counties with above-median rates of high-cost loans also saw larger decreases in the size of the labor force following mass layoffs, although the differences are not statistically significant. Additionally the counties had identical rates of out-migration. The similar out-migration rates are consistent with research finding that homeowners entering foreclosure usually move very short distances (Molloy and Shan, 2013), which are not captured in our intercounty migration data. These results show little evidence that high-cost mortgage exposure played a major role in impeding labor market adjustment.

\subsection{Disability Application Response}

So far we have focused on disability insurance enrollment as the measure of a permanent exit from the labor force, and have found no significant effects. However,

\footnotetext{
15 These HMDA data files (www.metrotrends.org/natdata/hmda/hmda_download.cfm) and the procedures for constructing them were initially developed by the Urban Institute to support DataPlace (www.dataplace.org). The data are licensed under the Open Database License (http:/www.metrotrends.org/natdata/ODbL.cfm).
} 
there is a large and growing literature that documents the strong link between economic conditions and disability insurance. To investigate this discrepancy further, we use information on applications to disability insurance.

There are two benefits to using application counts in addition to changes in disability insurance enrollment. First, applications may be a more accurate representation of the role of disability insurance as an outside option for workers struggling to find employment. Second, certain elements of the disability insurance process cause there to be factors that may delay enrollment in the program in ways unrelated to an applicant's characteristics, including the applicant's decision of the timing of when to apply (Autor et al., 2015). Delays may be caused by processing time determined exogenously by assignment to an examiner, or due to lengthy appeals.

The data we use was compiled from the Disability Research File, and contains county-level counts of applications, appeals, and allowances by gender and broad age groups. County-year cells that had a count of less than 10 were suppressed. More detail about these missing data is described in an appendix. We calculated the share of individuals in a county that applied for disability insurance by dividing the application count by the lagged population in that age group in a county. To estimate how application behavior responds to mass layoffs, we include these application rates on the left-hand side of equation 5 in a manner similar to previous analyses.

Panel A of Table 8 displays the effect of mass layoffs on disability insurance application. Overall, the effects are not statistically significant, though positive. There is, however, a statistically significant response among older workers: a one percent mass layoff increases application rates by about 0.007 percentage points.

One aspect of the mass layoffs data we have not exploited thus far is that mass layoff counts are also separately reported by age bands. Thus, Panel B of Table 8 shows the effect of age-specific mass layoffs - the share of those in a certain age band laid offon the application behavior of the same age band. Here, we find some evidence that very young and very old workers are responding to age-group specific mass layoffs. Focusing on those over 55, a layoff that affects one percent of the population over 55 in a county increases the application rate by 0.02 percentage points. 
We also test whether there are differences in the responses before and after the Great Recession; these results are in Table 9. We find that individuals aged over 55 responded much more strongly during the Great Recession to layoffs, which is evidenced both in the overall and age-specific results. Additionally, our results from Table 9 on individuals aged 55 and older imply that a 1 percent mass layoff increased DI application rates by 0.01 percentage points during the Great Recession. Given our results from Table 6 , that a 1 percent mass layoff decreases the labor force size by 0.22 percentage points, the DI application effect can explain almost 5 percent of the overall change in the labor force following a mass layoff.

\subsection{Robustness Checks}

We perform a number of robustness checks to our basic specification. First, we re-estimate equation 5, but also include a lead of the layoff share. If the lead is significant, it would suggest that counties experiencing mass layoffs were generally declining in a way that was predictable to individuals, suggesting that mass layoffs are not an unexpected labor demand shock. As shown in Table 10, we find that the lead coefficients are small and statistically insignificant.

Up to this point, our representation of the local labor market has been the county. However, many individuals commute across county lines for work, and so the county is a somewhat restrictive measure of the local labor market. To address this shortcoming, we aggregated all of our outcomes to the commuting zone level, which is a more natural definition of a local labor market, and includes all counties in the United States. Our estimates for those regressions are in Table 11. Our results using commuting zone level effects are very similar to our main results in Table 5, although we find a smaller residual, and the four channels of labor market exit explain 90 percent of the change in labor force due to mass layoffs. In results not shown, we allowed the effect of mass layoffs to differ before and during the Great Recession, and found similar patterns to Table 6: a larger decrease in labor force size during the Great Recession and a smaller effect on out-migration, which led to a larger estimated residual during the Great Recession. 
The analyses so far quantify the channels of labor market exit and compared their magnitudes, with migration being the predominant type of exit. Bound and Holzer (2000) find that different segments of the population adjust to labor market changes to different extents. With this heterogeneity in mind, we measure the extent to which an area's demographic composition changes with mass layoff events. We use the share of the population in various age and race categories as the dependent variable in equation 5. Table 12 displays the results. While the effects are not statistically significant, the signs of the coefficients are consistent with previous literature on migration propensities, as well as our key result that migration is the predominant labor market exit. The effects imply that following a mass layoff, the share of youth and adults that are early-career age decrease, suggesting that they are more likely to migrate in response to a mass layoff. On the other hand, the positive coefficients for the share of people ages 45-59 implies that older workers are less likely to migrate in response to a mass layoff. We also find that the share of the county that is white decreases, while the share that is black increases, suggesting differential likelihood of migration by race, similar to the results from Bound and Holzer (2000).

\section{Conclusion}

Researchers have long been interested in how individuals respond to adverse labor market conditions, and how these responses serve to equilibrate the labor market. Blanchard and Katz (1992) was the first paper to suggest that labor mobility was central to this adjustment process. However, in the years since the Blanchard and Katz study, relatively little work has directly examined mobility in the aftermath of specific local labor market shocks, while mobility rates have been in secular decline. ${ }^{16}$ Additionally, the role of mobility in labor market adjustment has taken center stage as we emerge from the Great Recession and see evidence that labor mobility seems to be lower than at any time in recent history. This study attempts to bring these two lines of literature together, examining mobility and other labor force adjustments to county-level mass layoff measures.

\footnotetext{
${ }^{16}$ A notable exception is Zou (2015).
} 
We find that a layoff of one percent of a county's labor force leads to a decrease in the county labor force of 0.19 percentage points, and further find that migration accounts for a large share of this change. In all, our four exit channels - in-migration, out-migration, retirement, and DI-account for about 55 percent of the net labor force change following a mass layoff. Additionally, we show that non-participation has increased in the Great Recession.

Our finding of increased non-participation during and following the Great Recession raises two important questions for further research. First, while there is anecdotal evidence of what non-participants do with their time, to our knowledge there is no empirical work quantifying the specific nature of non-participation. These former workers may be working in informal markets, or they may be members of households with multiple earners. Additionally, it is unclear to what extent the non-participation we observe in the Great Recession is temporary or permanent, and whether we should expect these former workers to return to the labor force after labor market conditions improve. As with the long-term unemployed, it is likely that the skills of these non-participating individuals have decayed, and they may be less productive upon re-entering the labor force.

Second, our results on non-participation do not speak to the effects of nonparticipation on the aggregate labor market. While some researchers have tried to address this issue broadly (Smith, 2014), much more research needs to be done on the margin of non-participation in response to negative shocks. In particular, many job search models do not consider non-participation as a separate state from unemployment. Most critically, it will be important to continue to study non-participation following the Great Recession to understand whether this is a temporary or permanent feature of our local labor markets. 


\section{References}

Autor, David H., David Dorn and Gordon H. Hanson. 2013. "The China Syndrome: Local Labor Market Effects of Import Competition in the United States." American Economic Review, 103(6): 2121-68.

Autor, David H., Nicole Maestas, Kathleen J. Mullen, and Alexander Strand. 2015."Does delay cause decay? the effect of administrative decision time on the labor force participation and earnings of disability applicants." NBER Working Papers20840, National Bureau of Economic Research, Inc

Autor, David H., and Mark G. Duggan. 2003 "The rise in the disability rolls and the decline in unemployment." The Quarterly Journal of Economics, 118(1):157205.

Bartik, Timothy J. 1991. "Who benefits from state and local economic development policies?." Books from Upjohn Press .

Bartik, Timothy J. 1996. "The Distributional Effects of Local Labor Demand and Industrial Mix: Estimates Using Individual Panel Data." Upjohn Working Papers and Journal Articles, W.E. Upjohn Institute for Employment Research.

Black, Dan, Kermit Daniel, and Seth Sanders. 2002. "The impact of economic conditions on participation in disability programs: Evidence from the coal boom and bust." American Economic Review, 92(1):27-50.

Blanchard, Olivier J., and Lawrence F. Katz. 1992. "Regional evolutions.” Brookings Papers on Economic Activity, 23(1):1-76.

Bosworth, Barry P., and Gary Burtless. 2010. "Recessions, wealth destruction, and the timing of retirement." Working Papers, Center for Retirement Research at Boston College wp2010-21, Center for Retirement Research.

Bound, John and Harry J. Holzer. 2000. "Demand shifts, population adjustments, and labor market outcomes during the 1980s". Journal of Labor Economics, 18(1):20-54.

Burkhauser, Richard V., J.S. Butler and Gulcin Gumus. 2004. "Dynamic programming model estimates of social security disability insurance application timing." Journal of Applied Econometrics, 19(6):671-685. 
Chan, Sewin and Ann H. Stevens. 1999. "Job loss and retirement behavior of older men." NBER Working Papers6920, National Bureau of Economic Research, Inc.

Coile, Courtney C., and Phillip B. Levine. 2011. "The market crash and mass layoffs: How the current economic crisis may affect retirement." The B.E. Journal of Economic Analysis \& Policy, 11(1):1-42.

Charles, Kerwin K., Erik Hurst, and Matthew J. Notowidigdo. 2013. "Manufacturing decline, housing booms, and non-employment.” Working Paper 18949, National Bureau of Economic Research.

Davies, Paul S., Michael J. Greenwood, and Haizheng Li. 2001. "A conditional logit approach to US state-to-state migration.” Journal of Regional Science, 41(2), 337-360.

Erceg, Christoper J., and Andrew T. Levin. 2013. "Labor Force Participation and Monetary Policy in the Wake of the Great Recession," CEPR Discussion Papers 9668, C.E.P.R. Discussion Papers.

Fogli, Alessandra, Enoch Hill and Fabrizio Perri. 2012. "The geography of the great recession." In NBER International Seminar on Macroeconomics 2012, NBER Chapters. National Bureau of Economic Research, Inc.

Frey, William H. 2009. "The Great American Migration Slowdown: Regional and Metropolitan Dimensions.” Mimeo.

Goda, Gopi S., John B. Shoven and Sita N. Slavov. 2012. "Does stock market performance influence retirement intentions?" Journal of Human Resources, 47(4):1055-1081.

Greenwood, Michael J. 1997. "Internal migration in developed countries." Handbook of population and family economics, 1, 647-720.

Gross, Emily. 1999. "Internal revenue Service area-to-area migration data: Strengths, limitations, and current trends." IRS Statistics of Income (SOI) Bulletin.

Hoynes, Hillary. 2000. "Local Labor Markets And Welfare Spells: Do Demand Conditions Matter?" The Review of Economics and Statistics, 82(3):351-368.

Kreider, Brent. 1998. "Workers' applications to social insurance programs when earnings and eligibility are uncertain." Journal of Labor Economics, 16(4):84877. 
Kuka, Elira. 2015. "Quantifying the Benefits of Social Insurance: Unemployment Insurance and Health.” Job Market Paper..

Kwok, Joyce, Mary Daly and Bart Hobijn. 2010. "Labor Force Participation and the Future Path of Unemployment,” FRB SF Economic Letter 2010-27.

LaLumia, Sara. 2013. "The EITC, Tax Refunds and Unemployment Spells." American Economic Journal: Economic Policy. 5(2): 188-221.

Lindo, Jason M. 2015. "Aggregation and the estimated effects of local economic conditions on health." Journal of Health Economics, 40: 83-96.

Lundberg, Shelly. 1985. “The added worker effect.” Journal of Labor Economics, 3(1), 11-37.

Mattingly, Marybeth J., and Kristin E. Smith. 2010. "Changes in wives' employment when husbands stop working: a recession-prosperity comparison." Family Relations, 59: 343-357.

Molloy, Raven, Christopher L. Smith, and Abigail Wozniack. 2011. "Internal Migration in the United States," Journal of Economic Perspectives, vol. 25(3), pages 17396.

Molloy, Raven and Hui Shan. 2013."The Post-foreclosure Experience of U.S. Households," Real Estate Economics, American Real Estate and Urban Economics Association, vol. 41(2), pages 225-254, 06.

Moulta-Ali, Umar. 2013. "Social Security Disability Insurance (SSDI): The Five-Month Waiting Period for Benefits." Congressional Research Service Report.

Notowidigdo, Matthew J. 2013. "The incidence of local labor demand shocks." Working Paper 17167, National Bureau of Economic Research.

Peri, Giovanni and Chad Sparber, 2011. "Assessing inherent model bias: An application to native displacement in response to immigration," Journal of Urban Economics, Elsevier, vol. 69(1), pages 82-91.

Rappaport, Jordan. 2004. “Why are population flows so persistent?”, Journal of Urban Economics, Volume 56, Issue 3, Pages 554-580.

Ravikumar, B. and Lin Shao. 2014. "Discouraged Workers: What Do We Know?" Federal Reserve Bank of St. Louis Economic Synopses, 2014, No. 6. 
Saks, Raven E., and Abigail Wozniak. 2011. "Labor reallocation over the business cycle: new evidence from internal migration.” Journal of Labor Economics, 29(4):697739.

Smith, Christopher L. 2014. "The Effect of Labor Slack on Wages: Evidence from StateLevel Relationships," FEDS Notes 2014-06-02. Board of Governors of the Federal Reserve System (U.S.).

Stevens, Ann H. and Sewin Chan. 1999. "Employment and retirement following a latecareer job loss." American Economic Review, 89(2):211-216.

Sullivan, Daniel and Till von Wachter. 2009. "Job displacement and mortality: an analysis using administrative data.” Quarter Journal of Economics. 124(3): 12651306.

Wozniak, Abigail. 2010. “Are college graduates more responsive to distant labor market opportunities?" Journal of Human Resources, 45(4), 944-970.

Zou, Ben. 2013. "The Local Labor Market Spillover Effects of Military Personnel Contractions." Job market paper. 


\section{Appendix A: Issues of Weighting, Trends, and the Year 2000}

This appendix serves to explain why we have opted to display un-weighted estimates in the main results throughout. We show first that the estimates for net labor force are unchanged if we weight, but do not include county-specific trends. Then we discuss differences in the results when including both weights and trends.

The first column of Table A1 shows the estimate of the total effect of a mass layoff (including lags) on net labor force change. Comparing the first, second, and third rows show similar estimates. However, in the fourth row, where we include weights as well as trends, our estimate shrinks considerably.

One reason why the estimate changes so much when we include both weights and trends is that the labor force changes in 2000 have some error built into them. The Bureau of Labor Statistics incorporated major changes and revisions to the employment and labor force numbers, which were adjusted between December 1999 and January 2000, and December 2002 and January 2003. The former adjustment is the largest of these adjustments, and also has the largest impact on our estimates. ${ }^{17}$ This suggests that the year 2000 is problematic. To show why this would affect our estimates, we demonstrate two main facts: (1) This adjustment differentially affected different sizes of counties (which would affect estimates with weighting); and (2) This adjustment would have affected the county-specific detrending of the estimates (which would be affect estimates with trends). Taken together, this would suggest that dropping the year 2000 should mitigate these problems. We show how this affects the estimates in the second column of Table A1, which shows that omitting the year 2000 for net labor force changes our estimates only when weighted with trends.

Again, there are two key conclusions from this exercise. First, the BLS adjustment differentially affected different sizes of counties. In order to see this fact, consider Figure A3. Each panel shows the distribution of net labor force changes, by quartile of county size in 1996. Most years $(1999,2001$, and 2002) the distributions are rather tight, and similar across county size. However, in 2000, everything is much more disbursed, and importantly, becomes more disbursed for smaller counties than for larger

${ }^{17}$ (http://www.bls.gov/cps/cpscomp.pdf), 
counties. While we know this is true in other years as well, it is much more stark in 2000. Therefore, this adjustment by the BLS differentially affected different sizes of counties.

The second key finding is that the BLS adjustment affects county-specific trends, differentially by size of county. The previous fact showed that the adjustment the BLS made had different effects on changes between large and small counties. Figure A4 graphs the average net LF changes over time, once again by quartile of county population in 1996. Notice that while the time series for counties in the fourth quartile of population evolves smoothly over time from 1996 to 2010, counties in the other quartiles do not follow the same smooth pattern. In fact, in 2000, the average for these counties spikes, and then falls back to its normal level the year before (the numbers in 1999 and 2001 are almost identical). For the smallest quartile, the 2003 adjustment is evident as well; but the other quartiles are unaffected.

If we include trends, then these changes for counties will change the value of the $\eta_{\mathrm{c}}$ in equation 5, and adjust the slope of the county-specific trend. However, because this effect is differential by county size, it will really only affect our estimates when we also weight.

One additional comment is warranted here. If only the smallest counties were affected by this problem, then weighting would diminish of the issue; however, Figure A4 shows that the bottom three quartiles of counties were affected, and so weighting does not mitigate the problem.

\section{Appendix B: SSDI Applications and Missing Data}

To maintain the confidentiality of SSDI applicants, the Social Security Administration suppressed cells in the county-level aggregation of the Disability Research File (DRF) if the count was less than 10. In order to allow us to observe aggregate counts, however, the DRF had counts suppressed for all subgroups it at least one subgroup had a count of less than 10 , but reported the aggregate number. ${ }^{18}$

\footnotetext{
${ }^{18}$ For example, if in county $\mathrm{X}$ in year YYYY there were 5 males under 30 years old who applied and 15 females, the cell for males under 30 and the cell for females under 30 would be suppressed. However, the cell for total applications under 30 would show a value of 20 . This keeps the confidentiality of the cell under 10 while allowing us to observe the aggregate count.
} 
Missing data are relatively common. In the study period, between 350 and 800 counties had missing totals each year, suggesting that this number of counties had fewer than 10 applicants at all. For the age breakouts, the number of missing observations is greater. For the older age groups (45-54, 55 and over) approximately a third of counties were not reported, while in some years half of counties were not reported for the younger age groups (under 30, 31-44). Approximately half (47 percent) of counties had nonmissing data in all years.

These missing data do not reflect inconsistencies in the data, but are rather the results of small numbers of applications. As such, our preferred specification, reported in the body of this paper, drops these missing observations. For robustness we also explored other strategies.

Table A2 shows the results of various missing-data specifications. Panel A shows a summary of the results from table A2. Panel B excludes any county that ever had missing data. Panels $\mathrm{C}, \mathrm{D}$, and $\mathrm{E}$ assign values of 0,1 , and 9 to any missing cell, respectively. Assigning a 0 to all observations would generate a result based on the lower bound of missing data, while assigning a 9 would create a result based on the upper bound. Panel $\mathrm{F}$ assigns a random number, chosen from a uniform distribution between 0 and 9. There are negligible differences between these panels. 
Table 1: IV Results, First Stage

\begin{tabular}{lc}
\hline \hline & Unemployment Rate, $t$ \\
\hline Layoffs, $t$ & $0.3295^{* * *}$ \\
& $(0.0546)$ \\
Layoffs $t-1$ & $0.3322^{* * *}$ \\
& $(0.0563)$ \\
& $0.1042^{* * *}$ \\
Layoffs $t-2$ & $(0.0392)$ \\
& 26405 \\
\hline $\mathrm{N}$ & \\
\hline \hline
\end{tabular}

Standard errors in parentheses, clustered on state. Dependent variable is the unemployment rate. Each regression includes county and year fixedeffects, and county-specific trends. ${ }^{*} \mathrm{p}<.10,{ }^{* *} \mathrm{p}$ $<.05, * * * \mathrm{p}<.01$ 
Table 2: Effect of Unemployment Rate on Labor Force Exits

\begin{tabular}{lcc}
\hline \hline Net Labor Force & OLS & IV \\
\hline Unemp. Rate, $t$ & $\begin{array}{c}-0.00292^{* * *} \\
(0.000396)\end{array}$ & $\begin{array}{c}-0.00245^{* * *} \\
(0.0009)\end{array}$ \\
& & \\
In-Migration & & \\
Unemp. Rate, $t$ & $-0.000904^{* * *}$ & -0.00030 \\
& $(0.000238)$ & $(0.00039)$ \\
Out-Migration & & \\
Unemp. Rate, $t$ & $0.000577^{* * *}$ & $0.00095^{* * *}$ \\
& $(0.000129)$ & $(0.00023)$ \\
Disability Insurance & & \\
Unemp. Rate, $t$ & 0.000023 & 0.000082 \\
& $(0.000016)$ & $(0.000072)$
\end{tabular}

Retirement

$\begin{array}{lcc} & 0.000049 & 0.00013 \\ (0.00003) & (0.00017)\end{array}$

Standard errors in parentheses, clustered on state. Dependent variables are listed at the headings of each sub-panel. The first column is the OLS result, the second column is instrumenting the unemployment rate in year $t$ with mass layoff share in years $t, t-1, t-2$. Each regression includes county and year fixed-effects, and county-specific trends. ${ }^{*} \mathrm{p}<.10,{ }^{* *} \mathrm{p}<.05,{ }^{* * *} \mathrm{p}<.01$ 
Table 3: Summary Statistics, 2000-2010

\begin{tabular}{|c|c|c|c|}
\hline A: Summary Statistics & All Years & $2000-2006$ & $2007-2010$ \\
\hline Layoffs per Labor Force & $\begin{array}{c}0.0070 \\
(0.0098)\end{array}$ & $\begin{array}{c}0.0059 \\
(0.0084)\end{array}$ & $\begin{array}{c}0.0087 \\
(0.0118)\end{array}$ \\
\hline Layoffs Number & $\begin{array}{c}378.9123 \\
(1935.5590)\end{array}$ & $\begin{array}{c}314.1393 \\
(1390.7880)\end{array}$ & $\begin{array}{c}492.4453 \\
(2627.3110)\end{array}$ \\
\hline $\mathrm{N}$ & 33794 & 21518 & 12276 \\
\hline \multicolumn{4}{|l|}{ B: Incidence of Mass Layoffs } \\
\hline $1 \%$ of $\mathrm{LF}$ & $\begin{array}{c}0.6059 \\
(0.4887)\end{array}$ & $\begin{array}{c}0.4562 \\
(0.4982)\end{array}$ & $\begin{array}{c}0.5269 \\
(0.4994)\end{array}$ \\
\hline $2 \%$ of $\mathrm{LF}$ & $\begin{array}{c}0.3351 \\
(0.4721)\end{array}$ & $\begin{array}{c}0.2007 \\
(0.4006)\end{array}$ & $\begin{array}{c}0.2663 \\
(0.4421)\end{array}$ \\
\hline $3 \%$ of $\mathrm{LF}$ & $\begin{array}{c}0.1772 \\
(0.3819)\end{array}$ & $\begin{array}{c}0.0913 \\
(0.2881)\end{array}$ & $\begin{array}{c}0.1354 \\
(0.3422)\end{array}$ \\
\hline $4 \%$ of $\mathrm{LF}$ & $\begin{array}{c}0.0932 \\
(0.2908)\end{array}$ & $\begin{array}{c}0.0368 \\
(0.1882)\end{array}$ & $\begin{array}{c}0.0717 \\
(0.2580)\end{array}$ \\
\hline $5 \%$ of $\mathrm{LF}$ & $\begin{array}{c}0.0504 \\
(0.2188)\end{array}$ & $\begin{array}{c}0.0174 \\
(0.1309)\end{array}$ & $\begin{array}{c}0.0387 \\
(0.1929)\end{array}$ \\
\hline $\mathrm{N}$ & 3154 & 3154 & 3154 \\
\hline \multicolumn{4}{|c|}{ C: Components of Labor Force Change } \\
\hline Net Labor Force change & $\begin{array}{c}0.0031 \\
(0.0195)\end{array}$ & $\begin{array}{c}0.0040 \\
(0.0216)\end{array}$ & $\begin{array}{c}0.0016 \\
(0.0151)\end{array}$ \\
\hline Work-age Population change & $\begin{array}{c}0.0041 \\
(0.0108)\end{array}$ & $\begin{array}{c}0.0050 \\
(0.0112)\end{array}$ & $\begin{array}{c}0.0025 \\
(0.0099)\end{array}$ \\
\hline Inmigration-rate & $\begin{array}{c}0.0063 \\
(0.0229)\end{array}$ & $\begin{array}{c}0.0064 \\
(0.0230)\end{array}$ & $\begin{array}{c}0.0060 \\
(0.0223)\end{array}$ \\
\hline Outmigration-rate & $\begin{array}{c}0.0061 \\
(0.0199)\end{array}$ & $\begin{array}{c}0.0062 \\
(0.0193)\end{array}$ & $\begin{array}{c}0.0059 \\
(0.0206)\end{array}$ \\
\hline New DI & $\begin{array}{c}0.0012 \\
(0.0046)\end{array}$ & $\begin{array}{c}0.0012 \\
(0.0056)\end{array}$ & $\begin{array}{c}0.0013 \\
(0.0017)\end{array}$ \\
\hline New Retired & $\begin{array}{c}0.0022 \\
(0.0163)\end{array}$ & $\begin{array}{c}0.0017 \\
(0.0199)\end{array}$ & $\begin{array}{c}0.0030 \\
(0.0063)\end{array}$ \\
\hline Implied Residual & $\begin{array}{c}0.0016 \\
(0.0336)\end{array}$ & $\begin{array}{c}0.0001 \\
(0.0399)\end{array}$ & $\begin{array}{c}0.0042 \\
(0.0177)\end{array}$ \\
\hline $\mathrm{N}$ & 33794 & 21518 & 12276 \\
\hline
\end{tabular}

Incidence of mass layoffs refers to the share of counties that experienced at least one year where layoffs affected the noted percentage of the labor force. Work-age population is the population aged 15-65. The implied residual is calculated as described in the text, equation 3. 
Table 4: Effect of Layoff Events on Migration

\begin{tabular}{|c|c|c|c|c|}
\hline & (1) & $(2)$ & $(3)$ & $(4)$ \\
\hline \multicolumn{5}{|c|}{ Dependent Variable:Out-migration Rate } \\
\hline Layoffs & $\begin{array}{c}0.0437^{* * *} \\
(0.0110)\end{array}$ & $\begin{array}{c}0.0414^{* * *} \\
(0.00952)\end{array}$ & $\begin{array}{c}0.0392^{* * *} \\
(0.0107)\end{array}$ & $\begin{array}{c}0.0446^{* * *} \\
(0.0114)\end{array}$ \\
\hline L.Layoffs & & $\begin{array}{l}0.0186^{* *} \\
(0.0059)\end{array}$ & $\begin{array}{c}0.0144^{* * *} \\
(0.0053)\end{array}$ & $\begin{array}{c}0.0183^{* * *} \\
(0.0063)\end{array}$ \\
\hline L2.Layoffs & & & $\begin{array}{c}0.0076 \\
(0.0058)\end{array}$ & $\begin{array}{c}0.0181^{* * *} \\
(0.0058)\end{array}$ \\
\hline Total Effect & $\begin{array}{c}0.0437^{* * * *} \\
(0.011)\end{array}$ & $\begin{array}{c}0.0599 * * * \\
(0.0133)\end{array}$ & $\begin{array}{c}0.0612^{* * *} \\
(0.0159)\end{array}$ & $\begin{array}{c}0.0809^{* * *} \\
(0.0192)\end{array}$ \\
\hline \multicolumn{5}{|c|}{ Dependent Variable:In-migration Rate } \\
\hline Layoffs & $\begin{array}{c}-0.0403^{* * *} \\
(0.0145)\end{array}$ & $\begin{array}{c}-0.0335^{* *} \\
(0.0134)\end{array}$ & $\begin{array}{c}-0.0343^{* *} \\
(0.0145)\end{array}$ & $\begin{array}{l}-0.0192 \\
(0.0156)\end{array}$ \\
\hline L.Layoffs & & $\begin{array}{l}-0.0230 * \\
(0.0116)\end{array}$ & $\begin{array}{l}-0.0139 \\
(0.0109)\end{array}$ & $\begin{array}{l}-0.0015 \\
(0.0118)\end{array}$ \\
\hline L2.Layoffs & & & $\begin{array}{l}-0.0133 \\
(0.0082)\end{array}$ & $\begin{array}{c}0.0068 \\
(0.0106)\end{array}$ \\
\hline $\begin{array}{l}\text { Total Effect } \\
\text { (se) }\end{array}$ & $\begin{array}{c}-0.0403^{* * *} \\
(0.0145)\end{array}$ & $\begin{array}{c}-0.0565^{* *} \\
(0.0232)\end{array}$ & $\begin{array}{c}-0.0615^{* *} \\
(0.0284)\end{array}$ & $\begin{array}{l}-0.0139 \\
(0.0323)\end{array}$ \\
\hline County FEs & YES & YES & YES & YES \\
\hline $\begin{array}{l}\text { Year FEs } \\
\text { Trends }\end{array}$ & YES & YES & YES & $\begin{array}{l}\text { YES } \\
\text { YES }\end{array}$ \\
\hline $\mathrm{N}$ & 36755 & 33650 & 30566 & 30566 \\
\hline
\end{tabular}

Standard errors in parentheses, clustered on state. Dependent variables are listed at the headings of each panel. Layof $f s$ is the number of extended mass layoffs, divided by the lagged labor force. In-migration and outmigration rates are number of migrants divided by the sum of out-migrants and non-migrants. Each regression includes county and year fixed-effects; county specific trends are included in column $4 .{ }^{*} \mathrm{p}<.10,{ }^{* *} \mathrm{p}<.05,{ }^{* * *}$ $\mathrm{p}<.01$ 
Table 5: Total Effects of Mass Layoffs on Labor Market Exits

\begin{tabular}{lcccccc}
\hline \hline & $(1)$ & $(2)$ & $(3)$ & $(4)$ & $(5)$ & Estimated \\
& LF & In-Mig & Out-Mig & DI & Ret & Residual \\
\hline \multirow{2}{*}{ With Trends } & $\begin{array}{c}-0.1975^{* * *} \\
(0.0718)\end{array}$ & $\begin{array}{c}-0.0139 \\
(0.0323)\end{array}$ & $\begin{array}{c}0.0809^{* * *} \\
(0.0192)\end{array}$ & $\begin{array}{c}0.0072 \\
(0.0052)\end{array}$ & $\begin{array}{c}0.0034 \\
(0.0122)\end{array}$ & $\begin{array}{c}\mathbf{- 0 . 0 9 2 1} \\
(0.0821)\end{array}$ \\
\hline \multirow{2}{*}{ Without Trends } & $-0.1751^{* * *}$ & $-0.0615^{* *}$ & $0.0612^{* *}$ & $0.008^{* *}$ & 0.0031 & $\mathbf{- 0 . 0 4 1 4}$ \\
& $(0.0401)$ & $(0.0284)$ & $(0.0159)$ & $(0.0034)$ & $(0.0055)$ & $(0.0521)$ \\
\hline \multirow{2}{*}{ Y-Mean } & & & & & & \\
Observations & 30566 & 30566 & 30566 & 30566 & 30566 & \\
\hline \hline
\end{tabular}

Dependent variables are listed at the head of the column. The Total Effect displayed are the sum of the contemporaneous and lagged effects, from estimates of equation 5. The first panel displays estimates without trends, while the second panel displays estimates including county-specific trends. Standard errors in parentheses, clustered on state. Each regression also includes county and year fixed-effects. Estimated residual in bold calculated from Equation 2, and standard error calculated by summing up all the total effect squared standard errors and taking the square root. ${ }^{*} \mathrm{p}<.10,{ }^{* *} \mathrm{p}<.05,{ }^{* * *} \mathrm{p}<.01$ 
Table 6: Effect of Layoff Events, Interaction with Start of Great Recession

\begin{tabular}{lcccccc}
\hline \hline & $(1)$ & $(2)$ & $(3)$ & $(4)$ & $(5)$ & Estimated \\
& LF & In-Mig & Out-Mig & DI & Retired & Residual \\
\hline \multirow{2}{*}{ Layoffs, $t$} & 0.0589 & -0.00845 & $0.0488^{* *}$ & 0.00332 & 0.00553 & \\
& $(0.0489)$ & $(0.0246)$ & $(0.0208)$ & $(0.00396)$ & $(0.00963)$ & \\
Layoffs, $t-1$ & $-0.107^{* * *}$ & -0.00589 & $0.0282^{* * *}$ & 0.00429 & 0.0126 & \\
& $(0.0351)$ & $(0.0122)$ & $(0.00773)$ & $(0.00662)$ & $(0.0218)$ & \\
Layoffs, $t-2$ & $-0.0595^{*}$ & -0.00191 & $0.0255^{* * *}$ & 0.00114 & $-0.0119^{* *}$ & \\
& $(0.0333)$ & $(0.0124)$ & $(0.00758)$ & $(0.00231)$ & $(0.00555)$ & \\
Layoffs, $t \times$ Post-2007 & $-0.151^{* *}$ & -0.0160 & -0.00723 & -0.00141 & 0.00191 & \\
& $(0.0752)$ & $(0.0277)$ & $(0.0208)$ & $(0.00324)$ & $(0.00860)$ & \\
Layoffs, $t-1 \times$ Post-2007 & -0.0295 & 0.00713 & -0.0179 & -0.00248 & -0.0181 & \\
& $(0.0619)$ & $(0.0220)$ & $(0.0118)$ & $(0.00785)$ & $(0.0292)$ & \\
Layoffs, $t-2 \times$ Post-2007 & 0.0620 & 0.0224 & -0.0180 & 0.00196 & 0.0160 & \\
& $(0.0578)$ & $(0.0212)$ & $(0.0110)$ & $(0.00365)$ & $(0.0102)$ & \\
Total Effect, Pre & & & & & & \\
Total Effect, Post & -0.1076 & -0.0163 & $0.1025^{* * *}$ & 0.0088 & 0.0062 & $\mathbf{0 . 0 2 6 2}$ \\
& $(0.0836)$ & $(0.0369)$ & $(0.0285)$ & $(0.0095)$ & $(0.0297)$ & $(0.101)$ \\
\hline \multirow{2}{*}{ Y-Mean } & $-0.2266^{*}$ & -0.0027 & $0.0594^{* * *}$ & $0.0068^{*}$ & 0.0060 & $\mathbf{- 0 . 1 5 1 7}$ \\
Observations & $(0.1232)$ & $(0.0498)$ & $(0.0207)$ & $(0.0040)$ & $(0.0058)$ & $(0.1347)$ \\
\hline \hline Dep & & & & & & \\
& 0.004 & 0.057 & 0.057 & 0.001 & 0.002 & \\
& 30566 & 30566 & 30566 & 30566 & 30566 & \\
\hline
\end{tabular}

Dependent variables are listed at the head of each column. The coefficient estimates come from estimating equation 5, while allowing the effect to differ before and after 2007. Standard errors in parentheses, clustered on state. Each regression also includes county and year fixed-effects, as well as county-specific trends. Estimated residual in bold calculated from Equation 2, and standard error calculated by summing up all the total effect squared standard errors and taking the square root. ${ }^{*} \mathrm{p}<.10,{ }^{* *} \mathrm{p}<.05,{ }^{* * *} \mathrm{p}<.01$ 
Table 7: Geographic Decomposition of Migration Rates

\begin{tabular}{|c|c|c|c|c|c|}
\hline & $\begin{array}{c}(1) \\
\text { Total Migration } \\
\text { Rate }\end{array}$ & $\begin{array}{c}(2) \\
\text { In-State }\end{array}$ & $\begin{array}{c}(3) \\
\text { Out-of-State }\end{array}$ & $\begin{array}{c}(4) \\
\text { Adjacent }\end{array}$ & $\begin{array}{c}(5) \\
\text { Non-Adjacent }\end{array}$ \\
\hline \multicolumn{6}{|c|}{ A: Out-Migration } \\
\hline Total Effect & $\begin{array}{c}0.0859^{* * *} \\
(0.0210)\end{array}$ & $\begin{array}{l}0.01559 \\
(0.0105)\end{array}$ & $\begin{array}{c}0.0703^{* * *} \\
(0.0151)\end{array}$ & $\begin{array}{c}0.0005 \\
(0.0076)\end{array}$ & $\begin{array}{c}0.0854^{* * *} \\
(0.0184)\end{array}$ \\
\hline Y-Mean & 0.058 & 0.03 & 0.028 & 0.023 & 0.035 \\
\hline \multicolumn{6}{|c|}{ B: In-Migration } \\
\hline Total Effect & $\begin{array}{l}-0.0357 \\
(0.0286)\end{array}$ & $\begin{array}{l}-0.0058 \\
(0.0141)\end{array}$ & $\begin{array}{l}-0.0300 \\
(0.0207)\end{array}$ & $\begin{array}{l}-0.0072 \\
(0.0086)\end{array}$ & $\begin{array}{l}-0.0285 \\
(0.0251)\end{array}$ \\
\hline Y-Mean & 0.059 & 0.03 & 0.028 & 0.023 & 0.036 \\
\hline $\mathrm{N}$ & 39845 & 39845 & 39845 & 39845 & 39845 \\
\hline
\end{tabular}

Each panel is a different migration rate - the first is out-migration, and the second is in-migration. Dependent variables are listed at the head of each column, and are components of the migration rate listed at the head of the panel. The total effects come from the coefficients that come from estimating equation 5. Standard errors in parentheses, clustered on state. Each regression also includes county and year fixed-effects, as well as county-specific trends. ${ }^{*} \mathrm{p}<.10,{ }^{* *} \mathrm{p}<.05,{ }^{* * *}$ $\mathrm{p}<.01$ 
Table 8: Effect of Layoff Events on Disability Applications

\begin{tabular}{lccccc}
\hline \hline \multicolumn{1}{c}{$(1)$} & $(2)$ & $(3)$ & $(4)$ & $(5)$ \\
& Total & Under 30 & Age 30-44 & Age 45-54 & Age 55+ \\
\hline Panel A: All Layoffs & & & & \\
Total Effect & 0.0052 & 0.0140 & -0.0027 & 0.0119 & $0.0073^{* * *}$ \\
\multicolumn{7}{c}{$(0.0039)$} & $(0.0092)$ & $(0.0071)$ & $(0.0083)$ & $(0.0036)$ \\
\hline Panel B: Age-Specific Layoffs & & & & \\
Subgroup Effect & 0.0052 & $0.0269^{* * *}$ & -0.0027 & 0.0082 & $0.0286^{* * *}$ \\
& $(0.0039)$ & $(0.0111)$ & $(0.0071)$ & $(0.0073)$ & $(0.0085)$ \\
\hline Y-Mean & 0.0058 & 0.0062 & 0.0067 & 0.0108 & 0.0066 \\
Observations & 33599 & 19818 & 24558 & 25476 & 25850 \\
\hline \hline
\end{tabular}

Dependent variable for each column is the share of an age group that filed an application for disability insurance. The key independent variables in panel A are the number of laid off workers as a share of the county's labor force. For panel B, the key independent variables are the number of age-specific laid off workers as a share of the age-specific population. The reported coefficients are the sum of contemporaneous and two lagged effects. Standard errors in parentheses, clustered on state. Each regression also includes county and year fixed-effects, as well as county-specific trends. ${ }^{*} \mathrm{p}<.10,{ }^{* *} \mathrm{p}<.05,{ }^{* * *} \mathrm{p}<.01$

Table 9: Effect of Layoff Events on Disability Applications, Before and After Great Recession

\begin{tabular}{|c|c|c|c|c|c|}
\hline & $\begin{array}{c}(1) \\
\text { Total }\end{array}$ & $\begin{array}{c}(2) \\
\text { Under } 30\end{array}$ & $\begin{array}{c}(3) \\
\text { Age } 30-44\end{array}$ & $\begin{array}{c}(4) \\
\text { Age } 45-54\end{array}$ & $\begin{array}{c}(5) \\
\text { Age } 55+\end{array}$ \\
\hline $\begin{array}{l}\text { A: All Layoffs } \\
\text { Total Effect, Pre }\end{array}$ & $\begin{array}{c}0.0071 \\
(0.0045)\end{array}$ & $\begin{array}{l}0.0183^{*} \\
(0.0099)\end{array}$ & $\begin{array}{l}-0.0006 \\
(0.0088)\end{array}$ & $\begin{array}{c}0.0121 \\
(0.0099)\end{array}$ & $\begin{array}{c}0.0049 \\
(0.0043)\end{array}$ \\
\hline Total Effect, Post & $\begin{array}{c}0.0021 \\
(0.0047) \\
\end{array}$ & $\begin{array}{c}0.0073 \\
(0.0114)\end{array}$ & $\begin{array}{l}-0.0062 \\
(0.0083)\end{array}$ & $\begin{array}{c}0.0119 \\
(0.0113)\end{array}$ & $\begin{array}{l}0.0105^{*} \\
(0.0052)\end{array}$ \\
\hline $\begin{array}{l}\text { B: Age-Specific Layoffs } \\
\text { Total Effect, Pre }\end{array}$ & $\begin{array}{c}0.0071 \\
(0.0045)\end{array}$ & $\begin{array}{l}0.0361^{* *} \\
(0.0136)\end{array}$ & $\begin{array}{l}-0.0018 \\
(0.0087)\end{array}$ & $\begin{array}{c}0.0068 \\
(0.0093)\end{array}$ & $\begin{array}{c}0.0197 \\
(0.0110)\end{array}$ \\
\hline Total Effect, Post & $\begin{array}{c}0.0021 \\
(0.0047)\end{array}$ & $\begin{array}{c}0.0147 \\
(0.0149)\end{array}$ & $\begin{array}{l}-0.0036 \\
(0.0088)\end{array}$ & $\begin{array}{c}0.0099 \\
(0.0110) \\
\end{array}$ & $\begin{array}{c}0.0400^{* * *} \\
(0.0135)\end{array}$ \\
\hline $\begin{array}{l}\text { Y-Mean } \\
\text { Observations }\end{array}$ & $\begin{array}{l}0.0058 \\
33599\end{array}$ & $\begin{array}{c}0.0062 \\
19818\end{array}$ & $\begin{array}{l}0.0067 \\
24558\end{array}$ & $\begin{array}{l}0.0108 \\
25476\end{array}$ & $\begin{array}{l}0.0066 \\
25850\end{array}$ \\
\hline
\end{tabular}

Dependent variable for each column is the share of an age group that filed an application for disability insurance. The key independent variables in panel A are the number of laid off workers as a share of the county's labor force. For panel B, the key independent variables are the number of age-specific laid off workers as a share of the age-specific population. The reported coefficients are the sum of contemporaneous and two lagged effects. Standard errors in parentheses, clustered on state. Each regression also includes county and year fixed-effects, as well as county-specific trends. ${ }^{*} \mathrm{p}<.10,{ }^{* *} \mathrm{p}<.05,{ }^{* * *} \mathrm{p}<.01$ 


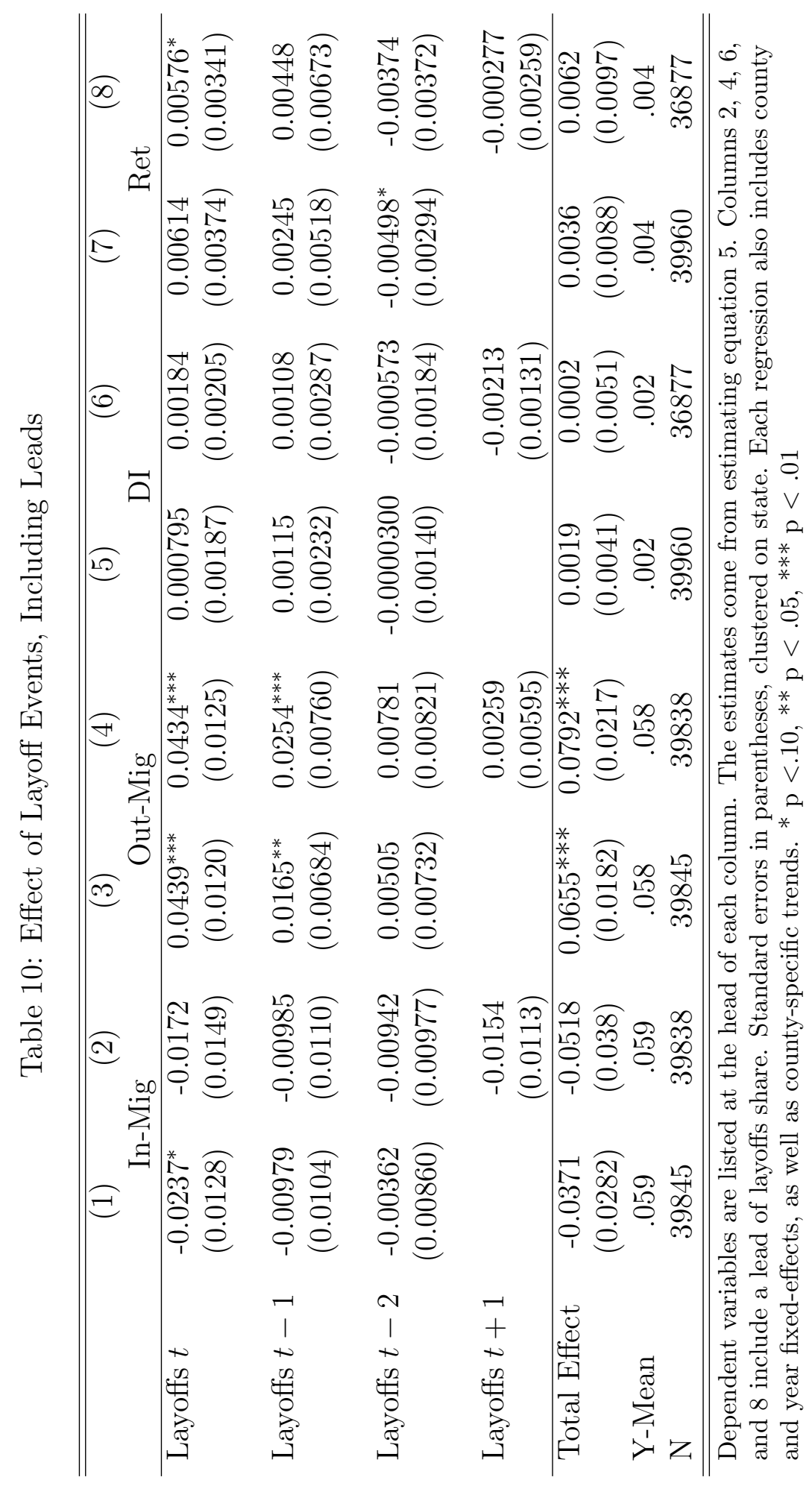


Table 11: Effect of Layoff Events at Commuting Zone Level

\begin{tabular}{lcccccc}
\hline \hline & $(1)$ & $(2)$ & $(3)$ & $(4)$ & $(5)$ & Estimated \\
& LF & In-Mig & Out-Mig & DI & Retirement & Residual \\
\hline Layoffs $t$ & -0.0393 & $-0.0486^{* * *}$ & $0.0576^{* * *}$ & 0.00201 & 0.0143 & \\
& $(0.0320)$ & $(0.0125)$ & $(0.0158)$ & $(0.00348)$ & $(0.0120)$ & \\
Layoffs $t-1$ & $-0.153^{* * *}$ & -0.0148 & $0.0220^{* * *}$ & $0.00475^{* *}$ & 0.00797 & \\
& $(0.0333)$ & $(0.0137)$ & $(0.00798)$ & $(0.00210)$ & $(0.00521)$ & \\
Layoffs $t-2$ & 0.0294 & 0.00790 & 0.0112 & -0.00626 & -0.0222 & \\
& $(0.0364)$ & $(0.0117)$ & $(0.00811)$ & $(0.00738)$ & $(0.0245)$ & \\
\hline Total Effect & $-0.1631^{* *}$ & $-0.0555^{*}$ & $0.0908^{* * *}$ & 0.0005 & 0.0001 & $\mathbf{- 0 . 0 1 6 2}$ \\
(se) & $(0.0676)$ & $(0.0291)$ & $(0.0222)$ & $(0.0037)$ & $(0.0105)$ & $0.0777)$ \\
Y-Mean & 0.0043 & 0.0579 & 0.0572 & 0.0009 & 0.0019 & \\
Observations & 8664 & 8664 & 8664 & 8664 & 8664 & \\
\hline \hline
\end{tabular}

Dependent variables are listed at the head of each column. The estimates come from estimating equation 5 , but the observation is the commuting zone-year. The total effects are the sum of the layoffs coefficients. Standard errors in parentheses, clustered on state. Each regression also includes commuting zone and year fixed-effects, as well as CZ-specific trends. Estimated residual in bold calculated from Equation 2, and standard error calculated by summing up all the total effect squared standard errors and taking the square root. ${ }^{*} \mathrm{p}<.10,{ }^{* *} \mathrm{p}<.05,{ }^{* * *} \mathrm{p}<.01$

Table 12: Effect of Layoff Events on Demographic Composition

\begin{tabular}{lcccccc}
\hline \hline & $(1)$ & $(2)$ & $(3)$ & $(4)$ & $(5)$ & \\
& Age 0-18 & Age 19-44 & Age 45-59 & Age 60 plus & Black & White \\
\hline Total Effect & -.0131 & -.0165 & .0157 & .0139 & .0068 & -.0045 \\
& $(0.0157)$ & $(0.0166)$ & $(0.0171)$ & $(0.0152)$ & $(0.0058)$ & $(0.0075)$ \\
\hline Y-Mean & 0.26 & 0.331 & 0.205 & 0.203 & 0.091 & 0.88 \\
Observations & 39926 & 39926 & 39926 & 39926 & 39926 & 39926 \\
\hline \hline
\end{tabular}

Dependent variable for each column is the share of the population fitting the description at the head of the column. The three panels are separate estimates for the whole time period, the effect before 2007, and the effect after 2007 The estimates come from estimating equation 5. Standard errors in parentheses, clustered on state. Each regression also includes county and year fixed-effects, as well as county-specific trends. ${ }^{*} \mathrm{p}<.10,{ }^{* *} \mathrm{p}<.05,{ }^{* * *} \mathrm{p}<.01$ 
Figure 1: Event Studies, 4\% Mass Layoff Event ( $N=118$ counties)

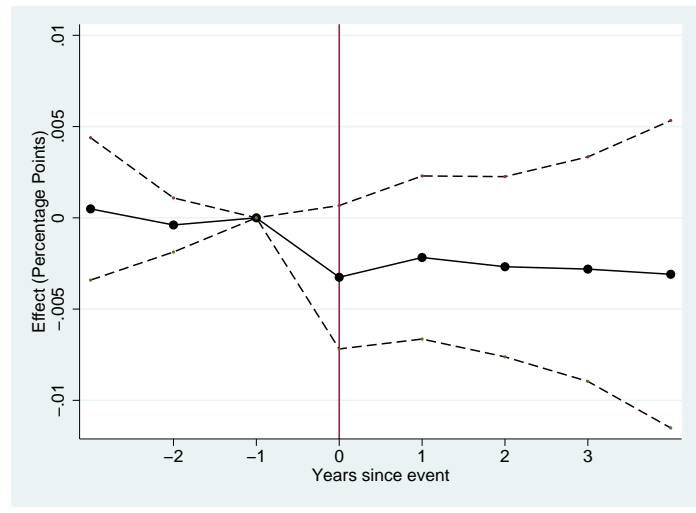

In-migration

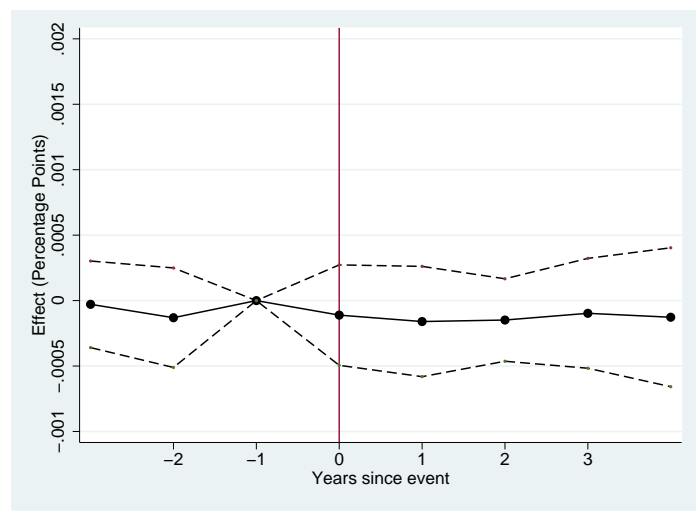

Disability

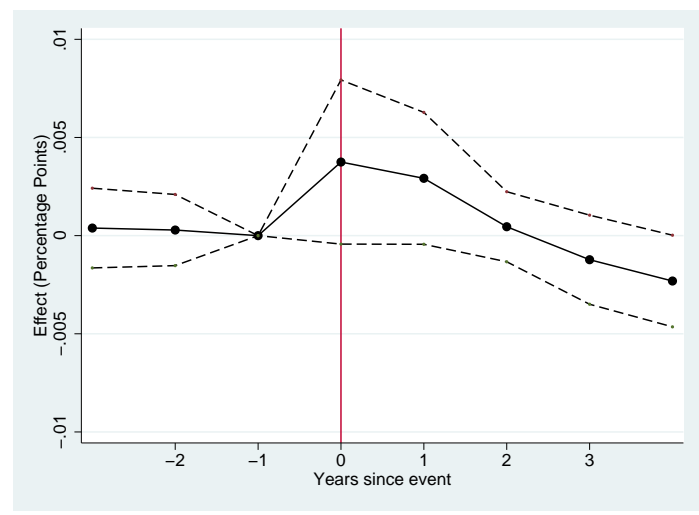

Out-migration

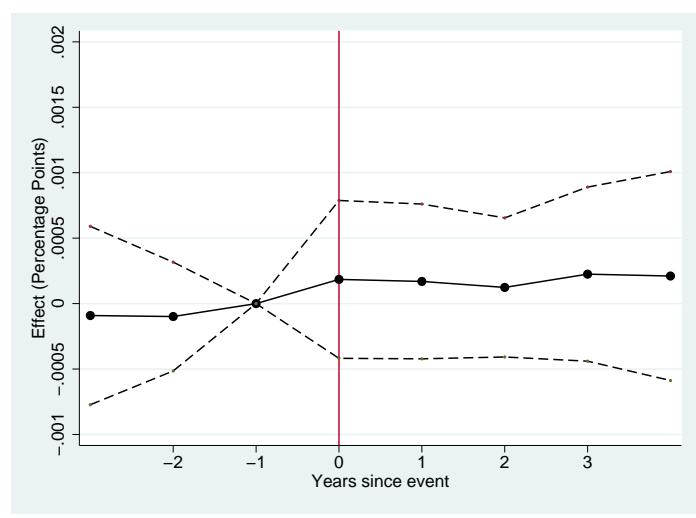

Retirement

Figures display coefficients from equation (5) in text, and a 95\% point-wise confidence interval is shown, with standard errors clustered at the state level. Outcome variables listed below each sub-figure. Event study methodology is described in greater detail in the text. Sample is restricted to counties that experienced just one layoff event surpassing four percent of the labor force in the years 2000-2007. Specifications include county and year fixed effects. 


\section{Appendix Figures and Tables}

Figure A1: Event Studies, 3\% Mass Layoff Event (N=196 counties)

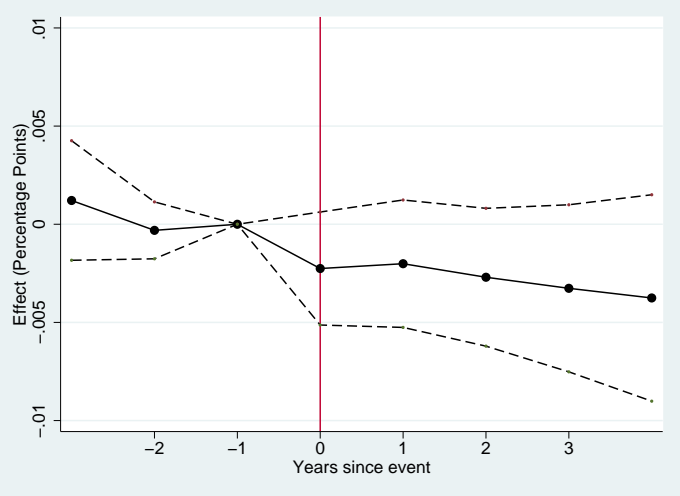

In-migration

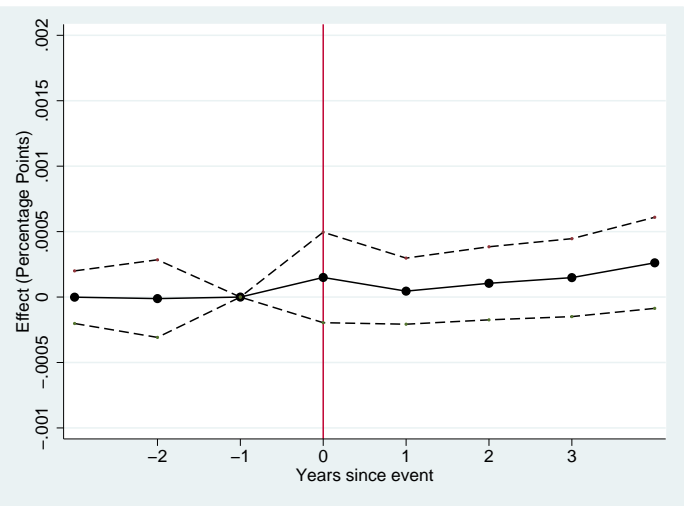

Disability

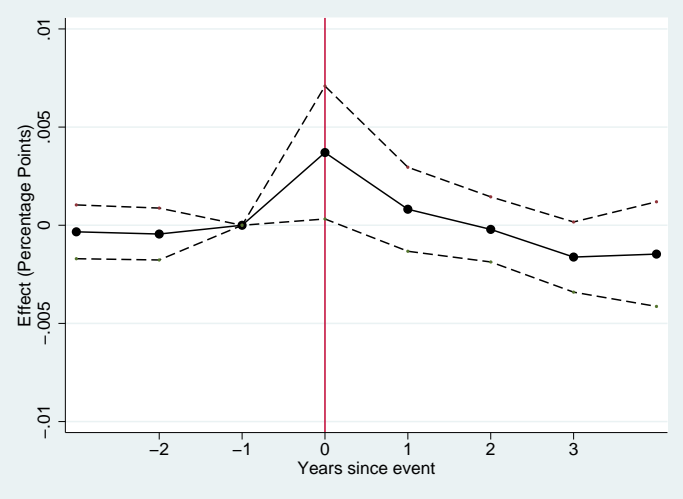

Out-migration

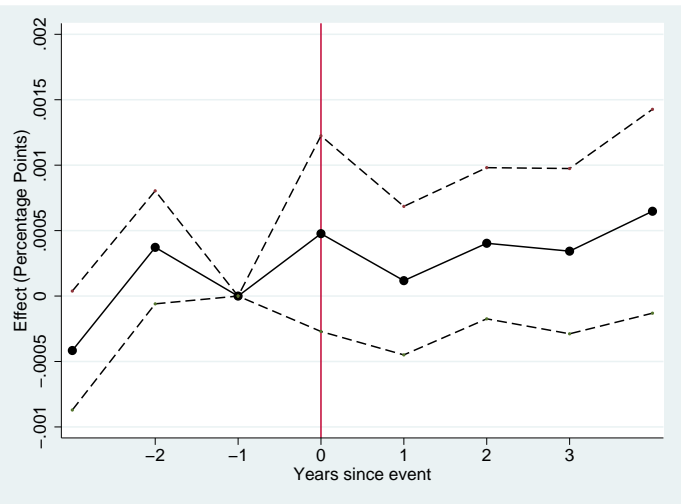

Retirement

Figures display coefficients from equation (5) in text, and a 95\% point-wise confidence interval is shown, with standard errors clustered at the state level. Outcome variables listed below each sub-figure. Event study methodology is described in greater detail in the text. Sample is restricted to counties that experienced just one layoff event surpassing three percent of the labor force in the years 2000-2007. Specifications include county and year fixed effects. 
Figure A2: Event Studies, 2\% Mass Layoff Event ( $\mathrm{N}=254$ counties)

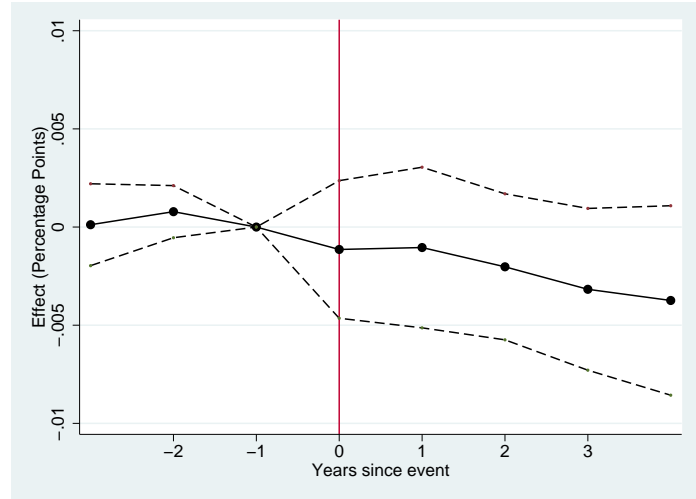

In-migration

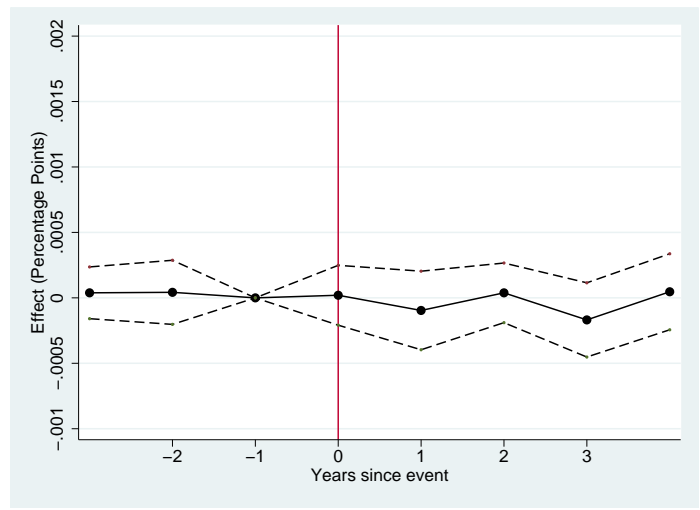

Disability

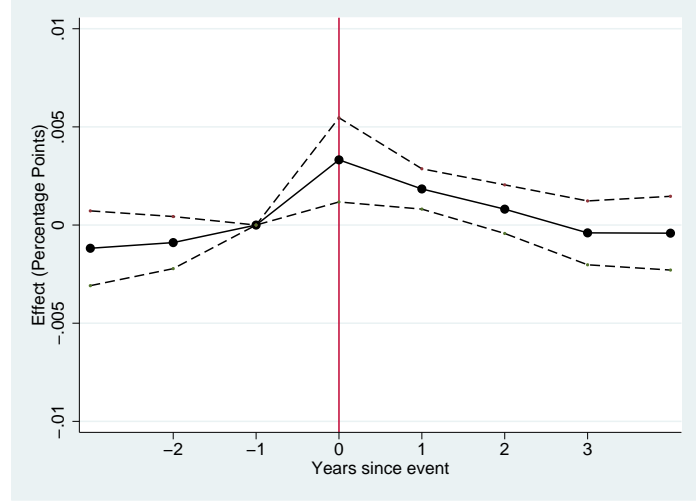

Outmigration

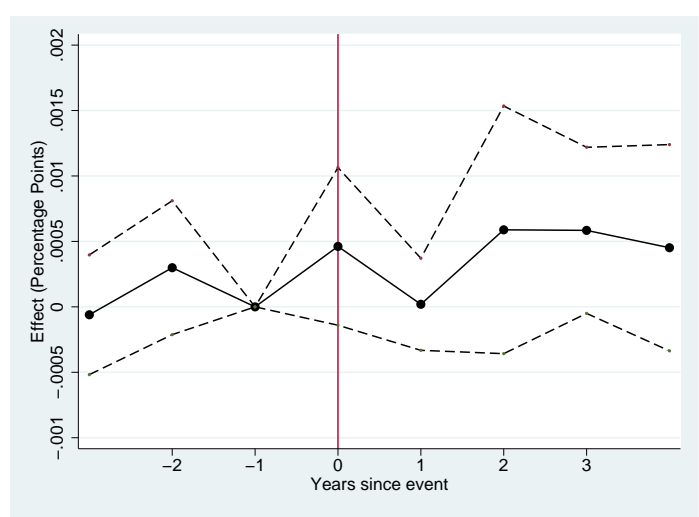

Retirement

Figures display coefficients from equation (1) in text, and a 95\% point-wise confidence interval is shown, with standard errors clustered at the state level. Outcome variables listed below each sub-figure. Event study methodology is described in greater detail in the text. Sample is restricted to counties that experienced just one layoff event surpassing two percent of the labor force in the years 2000-2007. Specifications include county and year fixed effects. 
Figure A3: Distributions of Net Labor Force Change, by Quartile and Year
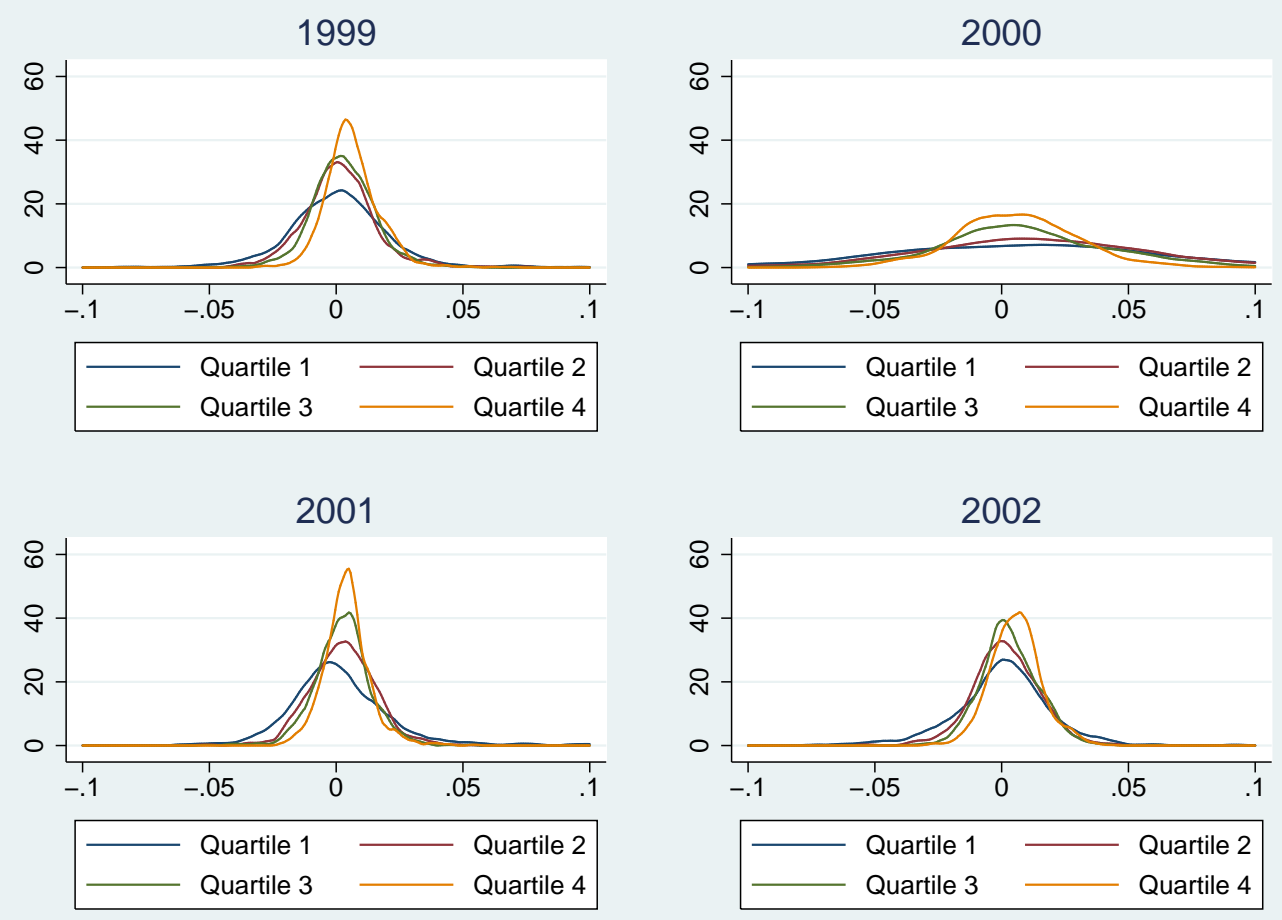

Figure A4: Average net LF changes over time, by quartile of county population

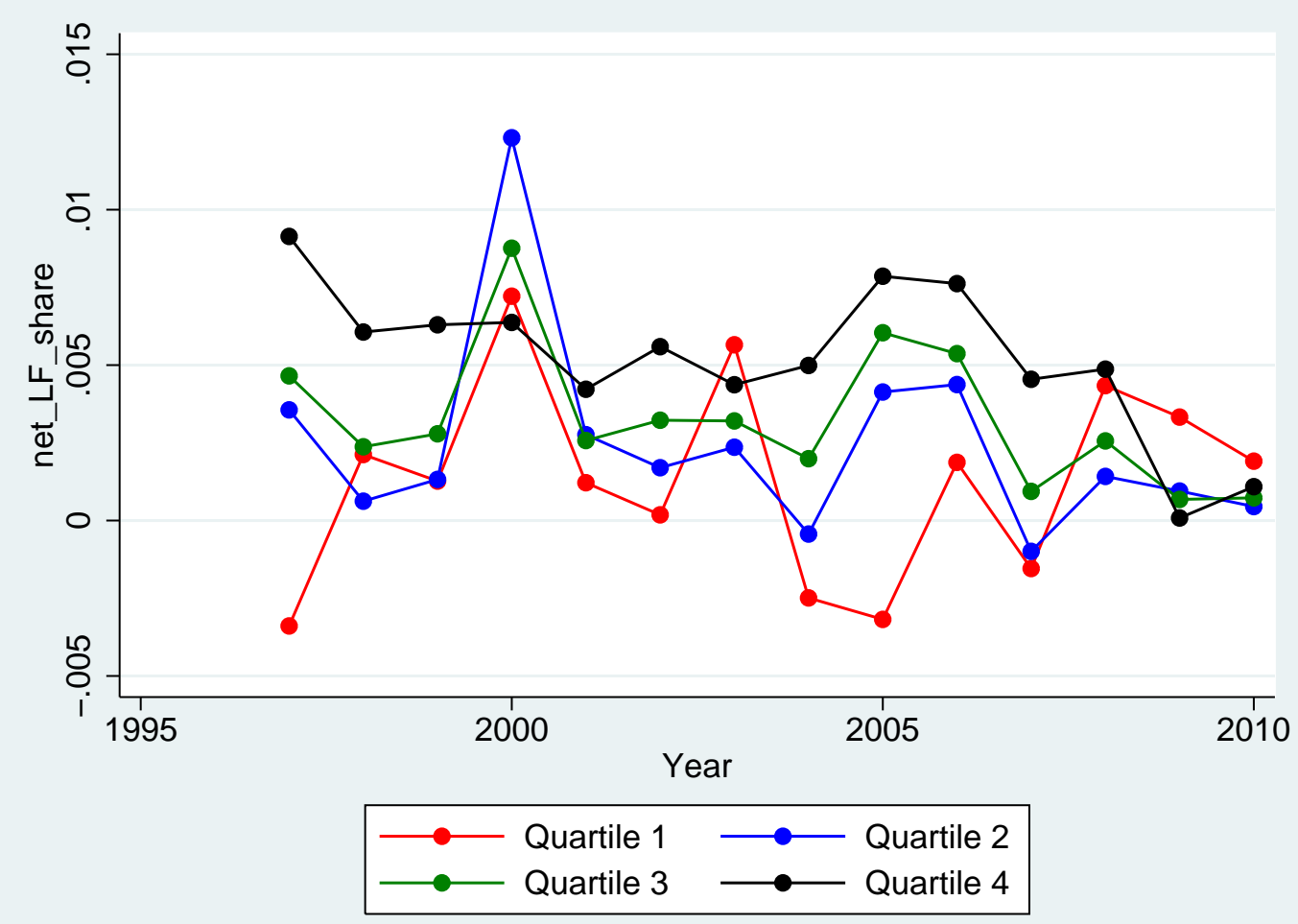


Table A1: Effect of Layoff Events on Net Labor Force

\begin{tabular}{|c|c|c|}
\hline & All years & Omitting 2000 \\
\hline \multicolumn{3}{|c|}{ A: Un-weighted } \\
\hline \multirow[t]{2}{*}{ No Trends } & -0.1513 & -0.2107 \\
\hline & $(0.0486)$ & $(0.0436)$ \\
\hline \multirow[t]{2}{*}{ Trends } & -.1501 & -0.2055 \\
\hline & $(0.0610)$ & $(0.0602)$ \\
\hline \multicolumn{3}{|c|}{ B: Weighted } \\
\hline \multirow[t]{2}{*}{ No Trends } & -0.1463 & -0.1812 \\
\hline & $(0.0681)$ & $(0.0606)$ \\
\hline \multirow[t]{2}{*}{ Trends } & -0.0527 & -.0999 \\
\hline & $(0.0757)$ & $(0.0784)$ \\
\hline
\end{tabular}

The dependent variable is change in labor force size. Each cell is a different regression, and the coefficients are the sum of the layoffs coefficients, estimated using equation 5 . The first column includes all years, while the second column excludes the year 2000. Panel A displays estimates from unweighted regressions, while Panel B displays estimates from regressions weighted by lagged county population. Standard errors in parentheses are clustered on state. Each regression also includes county and year fixed-effects; the second row of each panel includes trends. ${ }^{*} \mathrm{p}<.10,{ }^{* *} \mathrm{p}<$ $.05,{ }^{* * *} \mathrm{p}<.01$ 
Table A2: Robustness Check: Imputation of Missing Disability Application Data

\begin{tabular}{lccccc}
\hline \hline & Total & Under 30 & $31-44$ & $45-54$ & 55 over \\
\hline A. Preferred & & & & & \\
Total Effect & 0.0089 & 0.0146 & 0.0009 & 0.0178 & 0.0047 \\
& $(0.0037)$ & $(0.0120)$ & $(0.0059)$ & $(0.0087)$ & $(0.0057)$ \\
& 33599 & 20911 & 26406 & 27376 & 27733 \\
B. No-Missing & & & & & \\
Total Effect & 0.0073 & 0.0010 & 0.0063 & 0.0213 & 0.0048 \\
& $(0.0049)$ & $(0.0171)$ & $(0.0076)$ & $(0.0116)$ & $(0.0069)$ \\
& 19190 & 11533 & 20471 & 20627 & 20276 \\
C. Impute 0's & & & & & \\
Total Effect & 0.0107 & 0.0398 & 0.0088 & 0.0200 & 0.0087 \\
& $(0.0044)$ & $(0.0124)$ & $(0.0064)$ & $(0.0102)$ & $(0.0068)$ \\
& 39921 & 39921 & 39921 & 39921 & 39921 \\
D. Iimpute 9's & & & & & \\
Total Effect & 0.0104 & 0.0731 & -0.0139 & 0.0242 & 0.0127 \\
& $(0.0043)$ & $(0.0343)$ & $(0.0069)$ & $(0.0099)$ & $(0.0054)$ \\
& 39921 & 39921 & 39921 & 39921 & 39921 \\
E. Random Impute & & & & & \\
Total Effect & 0.0110 & 0.0553 & -0.0006 & 0.0244 & 0.0117 \\
& $(0.0042)$ & $(0.0242)$ & $(0.0065)$ & $(0.0098)$ & $(0.0052)$ \\
& 39921 & 39921 & 39921 & 39921 & 39921 \\
\hline \hline
\end{tabular}

Dependent variable for each column is the share of an age group that filed an application for disability insurance. The reported coefficients are the sum of contemporaneous and two lagged effects. Panel A drops cells with missing data. Panel B drops counties with missing data in any year. Panel $\mathrm{C}$ and D impute a 0 (minimum) or 9 (maximum) for each missing observation, and panel $\mathrm{E}$ imputes a number chosen randomly between 0 and 9 from a uniform distribution. Observations that were suppressed were randomly assigned a number between 0 and 9, uniformly. Standard errors in parentheses, clustered on state. Each regression also includes county and year fixed-effects, as well as county-specific trends. ${ }^{*} \mathrm{p}<.10,{ }^{* *} \mathrm{p}<.05,{ }^{* * *} \mathrm{p}<.01$ 